Eskişehir Osmangazi Üniversitesi ïBß Dergisi

Aralık 2020, C. 15, S. 3, $1159-1184$

Başvuru : 20.09.2019

Kabul : :06.05.2020

\title{
Sürdürülebilir Giysi Satın Almada Etik Unsurların Değerlendirimesi: Sosyal Ağ Kullanıcıları Üzerine Bir Araştırma ${ }^{1}$
}

\author{
Hatice Dağcı Büyük ${ }^{2}$ \\ Sevtap Ünal ${ }^{3}$ \\ Aysel Erciş ${ }^{4}$
}

\begin{abstract}
Sürdürülebilir Giysi Satın Almada Etik Unsurların Değerlendirilmesi: Sosyal Ağ Kullanıcıları Üzerine Bir Araştırma
\end{abstract}

Öz

Bu çalışmada, tüketicilerin sürdürülebilir giysiye yönelik tutum ve satın alma niyetleri araştırılmıştır. Sürdürülebilir giysiye yönelik tutum ve satın alma niyetinde, tüketicilerin etik özellikleri ve takip ettikleri sosyal ağların etkisi incelenmiştir. Aynı zamanda materyalizm, giysiye yönelik ilgilenimin ve suçluluk duygusunun bu ilişkide moderatör (düzenleyici) etkisi tespit edilmeye çalışımıştır. Araştırma sonuçlarına göre; etik özelliklerden altruizm ve etik yükümlüklük sürdürülebilir giysiye yönelik tutumu olumlu etkilemektedir. Tüketicilerin takip ettikleri sosyal ağlar ise hem tutum hem de satın alma niyeti üzerinde etkilidir. Ayrıca materyalizm eğiliminin, giysiye ilgilenimin ve suçluluk duygusunun sürdürülebilir giysiye yönelik tutum ile sürdürülebilir giysi satın alma niyeti arasında düzenleyici etkiye sahip olduğu tespit edilmiştir.

Anahtar Kelimeler: Sürdürülebilir Tüketim, Giyim ve Tekstil Sektöründe Sürdürülebilir Tüketim, Etik, Etik Özellikler, Sosyal Ağ Siteleri
Evaluation of Ethics Element in Purchasing Sustainable Clothing: A Research On Social Network Users

\begin{abstract}
The aim of this study is to investigate the attitudes and buying intentions of individuals towards sustainable clothing. The consumers' ethic traits and the impact of the social netwoks they follow have been examined in their attitudes towards sustainable clothing and intention to purchase. At the same time the regulatory effect of materialism, clothing involvementand guilt feelings in this relationship have been to be determined. According to the research results; among the ethical traits altruism and ethics obligation, positively affect the attitude towrds sustainable clothing. Social networks that consumers follow are impact on both attitude and purchasing intention. In addition, it has been determined that the tendency materialism, interest in clothing and guilt have a regulatory effect between the attitude towards sustainable clothing and the intention to purchase sustainable clothing.
\end{abstract}

Keywords: Sustainable Consumption, Sustainable Consumption in Clothing and Textile Sector, Ethics, Ethics Traits, Social Networking Sites

\section{Giriş}

Giyim ve tekstil sektörü hammaddeden üretim sürecine ve nihai ürüne, satıştan giysi kullanım ömrüne kadar tüm süreçlerde çevre ve sosyal açıdan birçok soruna neden olmaktadır. Şimdiki göstergelere göre bu sorunların önümüzdeki yıllarda daha da çok artması beklenmektedir. Global Fashion Agenda ve Boston Consulting Group (2017) öngörüsüne göre genel giysi tüketiminin 2030 yılına kadar \%62 oranında artması yani bugün 62 milyon tondan, 500 milyar T-shirt'e eşdeğerde, 102 milyon tona ulaşması beklenmektedir (Global Fashion Agenda and Boston Consulting Group, 2017: 9). Küresel pazarda ön görülen bu artışın neden olacağı çevresel ve sosyal problemler göz önünde bulundurulduğunda, bu problemlerin çözümü ve ortadan kaldırılması

${ }^{1}$ Bu çalışma ilk yazarın doktora tezi çalışmasından türetilmiştir.

2 Dr. hatice-dagci@hotmail.com , Yazar ORCiD bilgisi: https://orcid.org/0000-0001-7487-6492

3 Prof. Dr. İzmir Kâtip Çelebi Üniversitesi IỉBF, İşletme Bölümü, sevtap.unal@ikc.edu.tr. Yazar ORCiD bilgisi: https://orcid.org/0000-0002-3227-0756

${ }^{4}$ Prof. Dr. Atatürk Üniversitesi iiBF, İşletme Bölümü, ayercis1@yahoo.com. Yazar ORCiD bilgisi: https://orcid.org/00000002-9835-8574 
ancak daha fazla firmayı sürdürülebilir stratejileri benimsemeye teşvik etmekle mümkün olacaktır.

Küresel ekonomi üzerinde önemli etkilere sahip olan sektör, üretim ve tüketim aşamalarında birçok çevresel, sosyal ve etik sorunlara neden olmaktadır. Özellikle moda endüstrisinin aşırı tüketimi empoze etmesi bu sorunların daha da büyümesine neden olmaktadır. Modanın hızlı döngüsünün neden olduğu ucuz işçilik, çok fazla miktarda kaynak kullanımı, bunun yanında yüksek miktarda atık ve çevre kirliliğinin oluşması gibi çevresel ve sosyal etkilerin yanı sıra sürdürülebilir yöntemlerle üretilmeyen ürünlerin insan sağlığına olan zararları sürdürülebilir giyim ve tekstili gündeme getirmektedir (Allwood, vd., 2006; Türkmen, 2012; Oral vd, Dirgar ve Erdoğan, 2012). Sürdürülebilir giyim ve tekstil, kaynakların tükenip veya kalıc olarak hasar görmediği süreçler yoluyla üretilen ve aynı zamanda geri dönüştürülebilen giyim ve tekstil ürünlerini ifade etmektedir (Walter, 2009).

Giyim ve tekstil sektöründe sürdürülebilirlik konusuna tüketici perspektifinden yaklaşıldığında, tüketicilerin çevresel konulardaki farkındalıkları ve kaygılarının artmasıyla birlikte sürdürülebilir veya çevresel ürünlere yöneldikleri görülmektedir. Fakat sürdürülebilir tüketim bireylerin giysi satın alma kararlarını çok fazla etkilememektedir. Çünkü bireyler sürdürülebilir giyim ürünlerini oldukça maliyeti bulmakta, ürün seçeneklerinin az olduğunu, ürünlerin estetik ve işlevsel yönleriyle ilgili bir takım dezavantajlara sahip olduğunu düşünmektedir (Kong vd. 2016; Joergens, 2006). Giysi tercihi çoğu zaman tüketicilerin kimliğini yansıtmaktadır ve moda tüketicileri için de kimlik son derece önemlidir. Bu yüzden satın alma kararlarında sürdürülebilir ve etik unsurlar tüketiciler tarafından pek dikkate alınmamaktadır (McNeill ve Moore, 2015). Dolayısıyla giyim ve tekstil sektöründe tüketicilerin çevresel ilgisini ve sürdürülebilir satın alma davranışlarını teşvik etmek, giyim ve tekstil sektöründe de sürdürülebilir tüketimi yaygınlaştırma adına önem taşımaktadır.

Son yıllarda özellikle bazı lüks markaların sürdürülebilirlik ve çevresel anlamda sağlamış oldukları katkıyla beraber, farkındalıkların oluşması ve toplumsal bilincinin artması, sürdürülebilir biçimde üretilen giysiye yönelik tüketicilerin inanç ve tutumlarında değişiklik oluşturmaya başlamıştır (Yücel ve Tiber, 2018; Kılıç, 2013). Giyim ve tekstil sektöründe sürdürülebilir tüketimin sağlamasında, tüketici davranışlarının altında yatan unsurları tespit etmek davranışları etkilemek ve tüketim alışkanlıklarını iyiye doğru değiştirmek adına oldukça önemlidir. Bu bağlamda konuyla ilgili literatürdeki çoğu çalışmadan farklı olarak sürdürülebilir giysiye yönelik olumlu tutum ve satın alma niyeti oluşturmada etik olgusunun araştırılması, bireylerin giysi bağlamında çevreci veya sürdürülebilir tercihler yapmalarında etkili olacağı düşünülmektedir.

Tüketicilerin sosyal sorumlu giysi satın alma davranışını araştıran birçok çalışmada etik konusu ele alınmıştır. Çalışmalarda tüketicilerin etik tüketime önem verdikleri ancak bunu satın alma davranışlarına yansıtmadıkları ortaya çıkmıştır (Carrington vd. 2010; Markkula ve Moisander, 2012; Eckhardt vd. 2010). Bu çalışmada da etiksel konulara önem veren tüketicilerin sürdürülebilir giysi satın alma niyeti önündeki engellerin tespit edilmesinin sektörde sürdürülebilir tüketimin yaygınlaştırılması açısından önemli olacağı düşünülmektedir. Bu bağlamda materyalizm ve giysiye ilgilenim gibi tüketicilerle ilgili özellikleri ifade etmede kullanılan değişkenlerin tüketicilerin sürdürülebilir giysiye yönelik tutum ile satın alma niyeti arasındaki moderatör etkisini de araştırarak, bu değişkenlerden hangilerinin tüketicilerin sürdürülebilir giysi satın alma niyetlerini engellediği ortaya çıkarılmaya çalışılacaktır. Yine etik tüketimde oldukça önemli olan suçluluk duygusunun tutum ve satın alma niyeti arasındaki moderatör etkisi de incelenerek, tüketicinin hissetmiş olduğu suçluluğun satın alma niyetini 
olumlu yönde etkileyip etkilemediği belirlenmeye çalışılacaktır.

Diğer taraftan günümüzde bireyler sosyal ağları diğer bireyler, ürünler, markalar, kişiler ve konular hakkında bilgi kaynağı olarak değerlendirmektedir (Blackshaw ve Nazzaro, 2004). Sosyal ağlar aynı zamanda bireylerin satın alma davranışlarına etki etme ve yönlendirmede etkili bir araç olma özelliğine sahiptir. Bu yönüyle çalışmaya sosyal ağların dâhil edilmesi bireylerin sürdürülebilir giysiye yönelik karar alma süreçlerin de önemli bir faktör olacağı düşünülmektedir.

Giyim ve tekstil sektöründe bireylerin sürdürülebilir giysiye yönelik tutum ve satın alma niyetlerini kapsamlı olarak araştırmayı amaçlayan çalışma iki bölümden oluşmaktadır. Birinci bölümde literatür ve hipotezlere, ikinci bölümde ise araştırma modelini test etmek için gerekli analizlere, bulgulara ve bulgulara ilişkin sonuç ve önerilere yer verilmiştir.

\section{Kavramsal Çerçeve}

Tüketiciler etik veya sosyal sorumlu kararlar alırken sahip olduğu değerleri rehberlik etmektedir. Birçok çalışmada etik veya sürdürülebilir davranışlar kişisel değerlerle ilişkilendirilmiştir (Vermeir ve Vebreke, 2006; Niinimaeki, 2010; Jagel, vd., 2012). Değerler etik tüketimi belirlemede ve sınırlamada da önemli bir role sahiptir (Jagel vd. 2012: Kilbourne ve Beckmann 1998). Niinimaeki (2010)'a göre etik değerler sürdürülebilir giysi satın almada kilit bir faktördür ve tüketicilerin tutumlarını, satın alma davranışlarını etkilemektedir (Quitalo, 2014: 18). Bu bağlamda kişisel değerler etik davranışlarında temelini oluşturduğu için, çalışmayla ilgili olarak; giysi bağlamında sosyal sorumlu ya da sürdürülebilir ürünlere yönelik tutumları etkileyen tüketicilerin etik özelliklerinin ortaya çıkarılması tüketicilere sürdürülebilir davranış kazandırma açısından önem arz etmektedir.

Bireylerin sahip olduğu kişisel özellikler değerleriyle bağlantılı olarak ortaya çıkar (Hitlin, 2003). Yani bireylerin soyut inançları olarak değerler, belirli sorunların veya durumların değerlendirilmesinde merkezi bir rol oynayan kişisel özelliklerin çeşitli formlarına dönüşmektedir (Smith, 1982). Bu doğrultuda Homer ve Kahle (1988)'nin değer-tutum-davranış hiyerarşisi, çaIışmanın amacı doğrultusunda modifiye edilmiş ve çalışmada değerler yerine, etik özellikler temel alınmıştır. Tüketicilerin etik ya da sosyal sorumlu davranışlarını araştıran çalışmalarda tüketicilerin etik özelliklerini belirtmek için altruizm (özgecilik), etik kaygı ve etik yükümlülük değişkenleri kullanılmıştır (Bae, 2012). Literatürdeki çalışmalara dayanarak bu çalışmada da tüketicilerin etik özelliklerini belirlemede bu değişkenlere yer verilmiştir.

\section{Etik Özellikler}

Altruizm; kişinin bencil olmadan, gönüllü olarak diğerlerine fayda sağlamayı ilke olarak benimseyen ahlaki tutumudur (Gates ve Steane, 2009). Altruizm sürdürülebilir yaşam tarzını benimseyen ve çevresel konularda hassas olan tüketicilerin de sahip olduğu bir değerdir. Tüketicilerin çevresel, sosyal sorumlu ve etik davranmaları hususunda itici bir güç olan altruizm (Dietz vd, 2005; Culiberg ve Bajde: 2013; Bae, 2012), literatürde birçok çevresel araştırmaya da konu olmuştur (Dietz vd, 2005; Mostafa, 2006; De Groot vd, 2008; Bae, 2012; Ryan, 2014; Whitley vd. 2018). ilgili çalışmalarda altruizmin, çevresel ve sosyal sorumlu inanç ve davranışları anlamada önemli olduğu belirtilmiş; tüketicilerin tutum ve satın alma niyetini etkilediği ortaya çıkmıştır. Altruizm literatürde giyim ve tekstil sektörü bağlamında da araştııılmıştır. Çevreye duyarlı giysiler için tüketici tutumlarının araştırıldığı bir çalışmada alturizm, tüketici etkinliği ve mutluluk gibi değişkenlerin sürdürülür giysiye yönelik tüketici tutumlarını etkilediği belirlenmiştir (Reimers ve Magnuson; 2017). Discon (2000), kadın tüketicilerin sosyal sorumlu giysi satın 
alma niyetlerini araştırdığı çalışmasında konfor, uyum, kalite gibi ürün özellikleriyle birlikte altruizmin de satın alma niyeti üzerinde etkili olduğunu ortaya çıkarmıştır. Ayrıca Bae (2012)'de araştırmasında, tüketicilerin sosyal sorumlu giysiye yönelik tutumlarını altruizmin pozitif yönde etkilediği sonucuna ulaşmıştır.

Etik kaygı; bireylerin kişisel nedenleri yanı sıra diğer başka nedenlerle ortaya çıkan etik konularla ilgili endişeler yaşamasıdır (Cowe ve Williams, 2000). Çevresel ve sosyal sorunlara ilişkin ortaya çıkan kaygılar tüketicileri daha sorumlu seçimler yapmaya yöneltmektedir (Barnett ve Cloke, 2010). Etik kaygıların satın alma niyeti ve davranışları üzerindeki etkisini inceleyen çalışmalarla ilgili olarak, giyim ve tekstil sektörü belirli tüketici kaygılarının daha çok ortaya çıktığı bir alan olarak kabul edildiğinden, çalışmalar çoğunlukla giyim ve tekstil bağlamında yapılmıştır (Shaw vd, 2004; Jorgens, 2006; Valor, 2007). Örneğin etik kaygıların çevreye duyarlı moda ürünleri satın alma niyeti üzerindeki etkisine ilişkin olarak Kanada ve Fransa arasındaki kültürel farkı araştıran Cervellon vd. (2010), çalışmalarında etik kaygılar ve sağlıkla ilgili kaygıların çevreye duyarlı moda ürünleri satın alımında en önemli etken olduğunu belirlemiştir. Sneddon vd. (2013) ise araştırmalarında, tüketicilerin yün giysi tercihleri üzerinde tekstil sektörüne yönelik oluşan etik kaygıların önemli derecede etkili olduğunu belirlemişlerdir.

Etik yükümlülük; kişinin etik kurallara dayalı olarak belirli bir davranışı gerçekleştirmesi ya da gerçekleştirmemesi yönünde hissetmiş olduğu sorumluluk duygusudur (Ajzen, 1991:21). Etik yükümlülüğün önemi giderek artmaktadır. Çünkü tüketicilerin diğer tercihlerinde olduğu gibi giysi tercihlerinde de sosyal veya çevresel bağlamda sorumsuz davranışlar sergilemeleri durumunda, etik yükümlülükleri nasıl tavır takındıklarıyla ilgili olarak daha fazla önem kazanmaktadır (Dickson, 2006). Ayrıca tüketicilerin etik yönden sorumluluk duymaları, kurumsal sosyal sorumluluk anlayışını benimseyen giysi perakende markalarına yönelik inanç ve tutumlarının oluşturulması için temel oluşturmaktadır (Diddi, 2014). Literatürde etik yükümlülüğün, çevresel ve etik davranışlar açısından da önemli bir faktör olarak değerlendirilmektedir (Kaiser ve Shimoda, 1999; Sparks ve Shepherd, 2002; Oh ve Joon, 2014). Bireylerin ahlaki açıdan hissettikleri bu sorumluluk duygusu çevresel ve sosyal faaliyetlere karşı olumlu tutum oluşturmalarına ve etik davranışlar sergilemelerine neden olmaktadır (Bae, 2012).

Yukarıdaki açıklamalardan da anlaşıldığı üzere altruizm, etik kaygı ve etik yükümlülük gerek tüketicilerin giysi bağlamında sürdürülebilir tüketim tercihlerini, gerekse de çevresel ve sosyal sorumlu satın almaya yönelik tutumlarını olumlu yönde etkileyen önemli tüketici özellikleridir.

\section{Sosyal Ağ Etkisi}

Günümüzde, önemli bir trend haline gelen sosyal ağ uygulamaları tüketicilerin satın alma davranışlarını; elektronik ağızdan ağıza iletişim ve sosyal ağlarda tüketici etkileşimi olmak üzere temelde iki şekilde etkilemektedir (Dabran ve Li, 2012).

Elektronik ağızdan ağıza iletişim (E-WOM): E-WOM zaman ve mekân sınırı olmaksızın, tüketicilerin istedikleri yer ve zamanda en uygun şekilde, bilgi alışverişi yapmalarına olanak tanıyan, fikir ve deneyimlerini paylaşırken daha rahat hissetmelerini sağlayan bir iletişim biçimidir. Tüketiciler E-WOM'un güvenilirliğinin yüksek olduğunu düşünmektedir (Bickart ve Schindler, 2001; Godes ve Mayzlin, 2004). Çünkü pazarlamacılar tarafından çok sayıda satış iletişimine maruz kalan tüketiciler, E-WOM sonucu elde etmiş oldukları bilgilerin tarafsız ve objektif olduğuna inanmaktadır (Alsop vd. 2007). Somut ürünler dışında özellikle hizmetlerde, hizmetin soyutluk özelliğinden dolayı satın alma öncesi denenemezliği, ağızdan ağıza iletişimin önemini 
daha da artırmaktadır. Hizmetlerin karmaşıklık seviyesi arttığında ve algılanan risk düzeyi yükseldiğinde ise bu önem katlanarak artmaktadır (Özaslan ve Uygun, 2014: 72).

E-WOM'un sosyal ağ platformlarının çoğalması, çeşitlenmesi ve yaygınlaşmasıyla arttığı gözlenmektedir (İşlek, 2012: 94). Tüketiciler firmaların sayfalarını takip edip, görüş ve deneyimlerini paylaşabilmekteler, ayrıca diğer tüketicilerden gelen yorumları ve beğenileri görebilmektedir. On-line ortamlarda yapılan pozitif ya da negatif tüketici yorumları, tüketicilerin ürün ya da hizmetlere yönelik tutumlarını etkileyip, gelecekteki ürün ya da hizmet satın alma kararlarında da etkili olabilmektedir (Gürce ve Benli, 2017: 1136).

Sosyal Ağlarda Tüketici Etkileşimi: Tüketicilerin sosyal ağ sitelerinde diğer tüketicilerle etkileşim sağladığı aktivitelerle birlikte çevrimiçi davranışlarının hızla geliştiği görülmektedir. Tüketiciler sosyal ağ platformlarında paylaşımlar yaparak, diğer kullanıcıların paylaşımlarını okuyarak, yorum yaparak, onlarla etkileşim içinde olup daha aktif tüketici davranışı sergilemiş olmaktadır (Heinonen, 2011). Sosyal ağ sitelerinin kullanıcıları bu mecraları birçok sebebe bağlı olarak kullanmaktadırlar. Üyelerin kullanım amaçları sitelere göre farklılık gösterse de çoğunlukla aile ve arkadaşlarıyla iletişim kurmak, haberleşmek, bilgiye ulaşma, eğlenme, eğitim ve yeni arkadaşlar edinmek en önde gelen sebeplerdendir (İ̧̧lek, 2012; Eren, 2014). Bu bağlamda sosyal ağ platformları tüketicilerin ürün ya da markalarla ilgili olumlu veya olumsuz yorumlarını sosyal etkileşim içerisinde, diğer tüketicilerle paylaşabilecekleri bir ortam sağlamaktadır (Hennig vd. 2004). Tüketiciler, ürün ya da markalarla ilgili yorumlarını düşüncelerini sosyal ağ platformlarını kullanarak, ucuz bir şekilde dile getirebilir, büyük kitlelere kolayca ulaşabilme imkânı elde eder (Elsner vd. 2010). Tüketicilerin sosyal ağ sitelerini nasıl kullandıkları ve sosyal ağ sitelerinin bilgi edinme, eğitimi geliştirme ya da arkadaşları ile iletişim kurma gibi faktörler açısında ne kadar faydalı bir ortam olduğu yönündeki algıları tutum ve davranışlarını olumlu yönde etkilemektedir (Reiter, 2015; Barutçu ve Toma: 2013).

\section{Materyalizm}

Materyalizm tüketicinin dünyevi eşyalara verdiği önem olarak tanımlanmaktadır (Belk, 1985: 265). Richins (2004)'e göre materyalizm asıl yaşam hedeflerine ya da arzulanan durumlara ulaşmada maddi varlıkların sahiplenilmesi veya edinilmesine atfedilen önemdir (Richins, 2004,210 ). Materyalizmin en üst düzeylerinde, bu tür maddi varlıklar, kişinin hayatında merkezi bir yer tutar ve en büyük memnuniyet ve memnuniyetsizliklerin de nedeni olabilir (Belk, 1985: 265). Maddi varlıklara önem veren ve bunlara sahip olmayı yaşamlarının temel amacı haline getiren materyalist eğilimi yüksek olan tüketiciler, bu edinimleri için etik kuralları da ihlal etmektedir (Muncy ve Eastman, 1998: 138). Ayrıca materyalist tüketiciler tüketim davranışlarının çevresel sonuçlarına daha az ilgi duyar ve çevresel sorunları da algılama olasılıkları daha düşüktür (Polonsky vd.,2014; Kilbourne ve Pickett, 2008). Hurst vd. (2013)'e göre materyalist değerler ile çevreci tutum ve davranış sergileme arasında negatif ilişki vardır (Hurst vd., 2013: 258).

\section{Giysiye İlgilenimin}

Illgilenim kişinin kendi nesnel gereksinimlerine, değerlerine ve çıkarlarına dayalı olarak bir nesneye göstermiş olduğu ilgi düzeyi olarak tanımlanmaktadır (Zaichkowsky 1985: 342). Giysiye ilgilenim ise tüketicilerin giysiyle ilgili faaliyetlerini yaşamlarının merkezi bir parçası olarak ne ölçüde dikkate aldığı ve gösterdiği ilgiyi ifade etmektedir (O’Cass, 2004). Giysiye ilgilenim kavramının önemi, giyimin tüketiciler için önemli bir sembolik tüketim alanını temsil etmesinden dolayı tüketicinin kimliğini yansıtması ve toplumdaki rolünü tanımlamasından kaynaklanmaktadır (O'Cass, 2000: 547). 
Tüketiciler giysi satın alımını yüksek ilgilenimli bir eylem olarak değerlendirilmektedir (Fairhurst, 1989). Modanın sürekli ve döngüsel yapısı insanların modaya olan ilgilerinin artmasına ve dolayısıyla da giysilerine daha çok önem vermelerine neden olmaktadır (O'Cass, 2001: 48). Daha önce yapılan çalışmalarda giysiye ilgilenimin tüketicilerin çevresel odaklı olmayan satın alma davranışları üzerinde etkili olan faktörlerden biri olduğu görülmektedir (Fairhurst vd., 1989; Seo vd. 2001; Park vd.,2006; Jones ve Kim, 2010; Cengiz, 2017). Ayrıca literatürde, materyalist eğilimlerin tüketicilerin çevresel satın alma davranışlarını negatif yönde etkilediği (Joung, 2013; Rosenbaum ve Kuntze, 2003) gibi giysiye ilgilenimin de tüketicilerin çevresel odaklı satın alımlarını negatif yönde etkileyebileceği öne sürülmüştür (Bae,2012).

\section{Suçluluk Duygusu}

Suçluluk, psikolojik açıdan davranış kuralları ihlal edilince, eylemlerinin veya niyetlerinin yanlış olduğunu düşününce kişide ortaya çıkan duygusal sıkıntıdır (Tangney vd., 1996). Freedman vd (1967)'ye göre suçluluk kişinin ahlak veya etik standartlara aykırı hareket etmesinden kaynaklanan bir histir. Pazarlama açısından suçluluk ise, tüketiciler normları, değerleri veya içsel standartlarını ihlal ettiklerini düşündükleri zaman hissettikleri duygudur. Suçluluk hoş olmayan ve rahatsız edici bir duygusal sıkıntı olduğu için, tüketiciler bu duyguyu, değerlerini, toplumsal veya içsel normlarını ihlal etmeyen satın alma kararları alarak önlemeye çalışmaktadır (Bakar, Lee ve Hashim, 2013: 234).

Suçluluk duygusu sosyal sorumlu davranma ve etik karar alma süreçlerinde kişilerin günlük yaşantılarını önemli derecede etkilemektedir (Cohen, vd., 2013; Brennan ve Binney 2010; Hibbert vd. 2007; Arli vd., 2016). Dolayısıyla suçluluk duygusunun artması tüketicilerin sosyal olarak istenmeyen davranışlardan kaçınmasını sağlamakta (Tangney, 1996); aynı zamanda etik ve sosyal sorumlu davranma niyetlerine de olumlu yönde katkıda bulunmaktadır (Steenhaut ve Kenhove 2006; Peloza vd. 2013; Theotokis ve Manganari, 2015; Onwezen vd. 2013).

\section{Sosyal Kabul Görme Ön yargısı}

Literatürde etik tüketici davranışının araştırıldığı bir çok çalışmada metodolojinin iç geçerliğini artırmak için sosyal kabul görme ön yargısı ölçülmektedir. Buradaki amaç, katılımcıların ankette yer alan soruları gerçekte olduğundan daha sosyal olarak kabul edilebilir bir şekilde cevapladıklarında değişkenler arasındaki ilişkilerin bu durumdan olumsuz etkilenmesi ve etik çalışmalardan doğru sonuç elde edilememesidir. Etik tüketici davranışının araştırıldığı çalışmaların hassaslığı nedeniyle sosyal kabul görme ön yargısı ölçeğinin ankete dâhil edilmesiyle, etik tüketici davranışı hakkında daha doğru bilgi sağlanacağı düşünülmektedir (Bae, 2012). Bu bağlamda etik tüketimle paralel olarak sürdürülebilir tüketimin araştırıldığı bu çalışmada da sosyal kabul görme ön yargısı değişkeninin ankete eklenmesiyle araştırmanın geçerliliğinin sağlanması amaçlanmaktadır. 


\section{Araştırmanın Yöntemi}

\subsection{Araştırmanın Amacı, Kapsamı ve Kısıtları}

Çalışmanın ana amacı, etik özellikler çerçevesinde bireylerin sürdürülebilir giysiye yönelik tutum ve satın alma niyetlerinin araştırılmasıdır. Çalışmanın ana amacına bağı ı diğer alt amaçlarını ise; materyalizm ve giysiye ilgilenimin tüketicilerin sürdürülebilir giysi satın alma niyetini engelleyen veya olumsuz etkileyen faktörler olup olmadığını ortaya çıkarmak, sosyal ağ sitelerinin sürdürülebilir giysiye yönelik tüketici tutumlarını dolayısıyla satın alma niyetini pozitif yönde etkileyebilecek potansiyel bir mecra olup olmadı̆̆ını tespit etmek oluşturmaktadır.

Araştırmanın kapsamına İstanbul ilinde yaşayan ve aynı zamanda sosyal ağ sitelerini aktif olarak kullanan tüketiciler dâhil edilmiştir. Sosyal ağ sitelerinin son yıllarda insanların yaşamlarında önemli yer tutması ve tüketicilerin ürün ve hizmet satın alımlarında belirleyici ve yönlendirici olması sebebiyle araştırma kapsamına sosyal ağ sitelerini aktif olarak kullanan tüketiciler dâhil edilmiştir.

Araştırmanın sadece İstanbul ilinde yaşayan ve sosyal ağları aktif kullanan 18 yaş ve üzeri tüketicilere yönelik yapılması araştırmanın kısıtını oluşturmaktadır. Çalışmada tekstil ürünleri belirli bir marka dikkate alınmadan değerlendirmeye alınmıştır. Dolayısıyla elde edilen sonuçlar Türkiye, aynı zamanda giyim ve tekstil markaları açısından genellenemez.

\section{2. Örnekleme Süreci}

Araştırmanın ana kütlesini, İstanbul ilinde yaşayan 18 yaş ve üzeri tüketiciler oluşturmuştur. Ana kütlenin çerçevesini ise, İstanbul ilinde yaşayan 18 yaş ve üzeri sosyal ağ sitelerini aktif olarak kullanan tüketiciler oluşturmuştur.

Araştırma için hazırlanan anket formuna son şekli verilmeden ve veri toplanmasına geçilmeden önce 50 kişilik bir tüketici grubu ile ön anket çalışması yapılmış, cevaplayıcıların ölçeklerdeki ifadeleri değerlendirmeleri istenmiştir. İfadelerin anlaşılırlığını arttırabilmek amacıyla tüketicilerden gelen öneriler dikkate alınmış ve gerekli düzeltmeler sonrasında anket formunun son şekli verilmiştir. Anket çalışması 15 Ekim- 20 Kasım 2017 tarihleri arasında gerçekleştirilmiş ve 500 kişiden yüz yüze görüşme yoluyla veriler toplanmıştır.

\subsection{Veri Toplama Yöntem ve Aracı}

Araştırmada veriler, anket yöntemi kullanılarak toplanmıştır. Anketler, cevaplayıcılar ile yüz yüze görüşme şeklinde uygulanmıştır.

Anket formunda üç grup soru yer almaktadır. Bunlardan birinci grup sorular katılımcıların; sosyal ağ sitelerine erişmede en çok hangi teknolojiyi kullandığı, günlük sosyal ağlarda harcadıkları süre, en çok kullandıkları sosyal ağ sitesini belirlemek amacıyla hazırlanmıştır. İkinci grupta, etik özellikleri, subjektif normu, sosyal ağ kullanma ve algılamayı, sosyal ağ sitelerinin satın alma davranışına etkisini, giyim ve tekstil sektörünün çevresel etkileri ile ilgili bilgi sahibi olmayı, sosyal kabul görme ön yargısını, materyalizmi, giysiye ilgilenimi, suçluluk duygusunu, sürdürülebilir giysiye yönelik tutumu, sürdürülebilir giysi satın alma niyetini ölçmek üzere hazırlanan ifadeler yer almıştır. Üçüncü grupta ise katılımcıların demografik özelliklerini belirmek amacıyla hazırlanan sorulara yer verilmiştir.

Katılımcıların etik özellikler, normatif inanç, sosyal ağ kullanma ve algılama, sosyal ağ sitelerinin satın alma davranışına etkisi, sosyal kabul görme ön yargısı, materyalizm, giysiye ilgilenim, suçluluk duygusu, sürdürülebilir giysiye yönelik tutum, sürdürülebilir giysi satın alma niyeti ile 
ilgili ifadelere katılma dereceleri 5'li likert ölçeği (1= Kesinlikle Katılmıyorum, 5=Tamamen Katılıyorum) ile ölçülmüştür. Giyim ve tekstil sektörünün çevresel etkileri ile ilgili bilgi sahibi olma ile ilgili ifadelere katılma dereceleri ise $5^{\prime}$ li likert ölçeği (1=Kesinlikle Yanlış, 5=Tamamen Doğru) ile ölçülmüştür.

Etik özelliklerden altruizme ilişkin ifadeler Rushton vd. (1981)'in çalışmasından, etik kaygıya ilişkin ifadeler Dunlap vd. (2000), Hustvedt ve Dickson (2009)'un çalışmalarından, etik yükümlülüğe ilişkin ifadeler ise Kaiser ve Shimoda (1999), Sparks vd. (1995)'in çalışmalarından yararlanılarak oluşturulmuştur. Normatif inanç, normlara uyma motivasyonu sosyal ağ kullanma ve algılama, sosyal ağ sitelerinin satın alma davranışına etkisi, giyim ve tekstil sektörünün çevresel etkileri ile ilgili bilgi sahibi olma ve sürdürülebilir giysiye yönelik tutuma ilişkin ifadeler için Reiter (2015)'in çalışmasından yararlanılmıştır. Sosyal kabul görme ön yargısına ilişkin ifadeler Reynolds (1982)' nin çalışmasından, materyalizme ilişkin ifadeler Richins ve Dawson (1992)'nin çaIışmasından, giysiye ilgilenime ilişkin ifadeler Mittal (1995)'in çalışmasından, suçluluk duygusuna ilişkin ifadeler Marschall vd. (1994)'ün çalışmasından, sürdürülebilir giysi satın alma niyetine ilişkin ifadeler Kang vd. (2013)'ün çalışmalarından yararlanılarak aktarılmıştır.

Veriler SPSS 20.0 ve AMOS 20.0 istatistik programları yardımıyla analiz edilmiştir. Verilerin analizinde tanımlayıcı istatistikler, Doğrulayıcı Faktör Analizi (DFA) ve Yapısal Eşitlik Modeli (YEM) analizleri uygulanmıştır.

\subsection{Araştırma Modeli}

Araştırmanın amaçları doğrultusunda oluşturulan araştırma modeli Şekil 1'de gösterildiği gibidir

Şekil 1: Araştırma Modeli

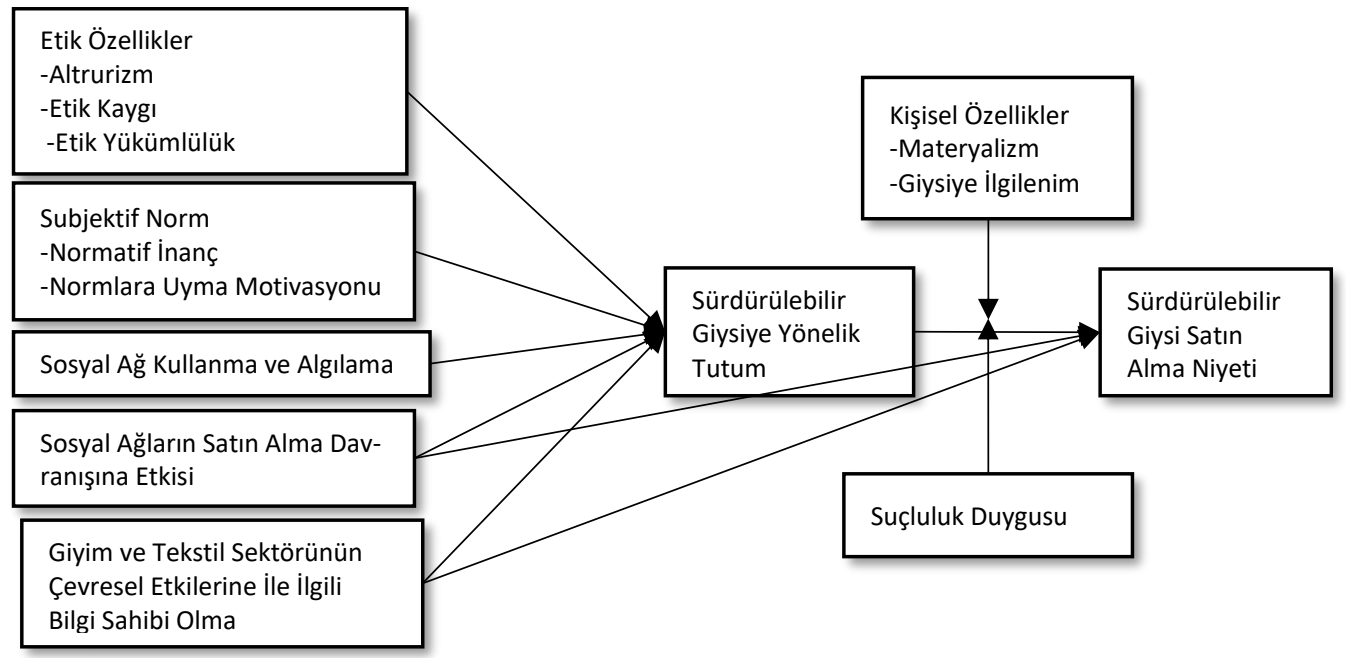


Araştırmanın amacı ve modeli doğrultusunda geliştirilen hipotezler aşağıdaki gibidir:

$\mathrm{H}_{1}$ : Etik özellikler sürdürülebilir giysiye yönelik tutumu olumlu yönde etkilemektedir. Bu araştırma hipotezi şu alt hipotezlere ayrılmıştır:

$\mathrm{H}_{1 \mathrm{a}}$ : Altruizm, sürdürülebilir giysiye yönelik tutumu olumlu yönde etkilemektedir.

$\mathrm{H}_{1 b}$ : Etik kaygı, sürdürülebilir giysiye yönelik tutumu olumlu yönde etkilemektedir.

$\mathrm{H}_{1 c}$ : Etik yükümlülük, sürdürülebilir giysiye yönelik tutumu olumlu yönde etkilemektedir.

$\mathrm{H}_{2:}$ Sürdürülebilir giysiyle ilgili subjektif norm sürdürülebilir giysiye yönelik tutumu olumlu yönde etkilemektedir. Bu araştırma hipotezi şu alt hipotezlere ayrılmıştır.

$\mathrm{H}_{2 a}$ : Normatif inançlar sürdürülebilir giysiye yönelik tutumu olumlu yönde etkilemektedir.

$\mathrm{H}_{2 b}$ : Normlara uyma motivasyonu sürdürülebilir giysiye yönelik tutumu olumlu yönde etkilemektedir

$\mathrm{H}_{3}$ : Sosyal ağları kullanma ve algılama sürdürülebilir giysiye yönelik tutumu olumlu yönde etkilemektedir.

$\mathrm{H}_{4 a}$ Sosyal ağların genel satın alma davranışına etkisi sürdürülebilir giysi satın alma niyetini olumlu yönde etkilemektedir.

$\mathrm{H}_{4 b}$ : Sosyal ağların genel satın alma davranışına etkisi sürdürülebilir giysiye yönelik tutumu olumlu yönde etkilemektedir

$\mathrm{H}_{5 a}$ : Giyim ve tekstil sektörünün çevresel etkileri ile ilgili bilgi sahibi olma, sürdürülebilir giysi satın alma niyetini olumlu yönde etkilemektedir.

$H_{5 b \text { : }}$ Giyim ve tekstil sektörünün çevresel etkileri ile ilgili bilgi sahibi olma, sürdürülebilir giysiye yönelik tutumu olumlu yönde etkilemektedir.

$H_{6}$ : Sürdürülebilir giysiye yönelik tutum, sürdürülebilir giysi satın alma niyetini olumlu yönde etkilemektedir.

$\mathrm{H}_{7}$ : Materyalizm sürdürülebilir giysiye yönelik tutum ile sürdürülebilir giysi satın alma niyeti arasındaki ilişkide moderatör etkiye sahiptir.

$\mathrm{H}_{8}$ : Giysiye ilgilenim sürdürülebilir giysiye yönelik tutum ile sürdürülebilir giysi satın alma niyeti arasındaki ilişkide moderatör etkiye sahiptir.

$\mathrm{H}_{9}$ : Suçluluk duygusu sürdürülebilir giysiye yönelik tutum ile sürdürülebilir giysi satın alma niyeti arasındaki ilişkide moderatör etkiye sahiptir. 


\subsection{Bulgular ve Tartışma}

\subsubsection{Araştırma Örneğine İlişkin Tanımlayıcı İstatistikler}

Katılımcıların cinsiyet, medeni hal, yaş, eğitim seviyesi, meslek, gelir durumlarına göre dağıIımları Tablo 1'de gösterilmiştir.

Tablo 1: Demografik Özellikler

\begin{tabular}{|c|c|c|c|c|c|}
\hline Cinsiyet & Frekans & Yüzde(\%) & Eğitim & Frekans & Yüzde(\%) \\
\hline Kadın & 274 & 54,8 & İlköğretim & 48 & 9,6 \\
\hline Erkek & 226 & 45,2 & Lise & 123 & 24,6 \\
\hline Toplam & 500 & 100 & Yüksekokul & 53 & 10,6 \\
\hline Medeni Hal & & & Üniversite & 234 & 46,8 \\
\hline Evli & 304 & 60,8 & Lisansüstü & 42 & 8,4 \\
\hline Bekâr & 196 & 39,2 & Toplam & 500 & 100 \\
\hline Toplam & 500 & 100 & Meslek & & \\
\hline Yaş & & & Özel sektör çalışanı & 182 & 36,4 \\
\hline $18-28$ & 96 & 19,2 & Serbest meslek & 65 & 13,0 \\
\hline $29-38$ & 139 & 27,8 & İşçi & 7 & 1,4 \\
\hline $39-48$ & 145 & 29,0 & Memur & 60 & 12,0 \\
\hline $49-58$ & 99 & 9,8 & Tüccar & 115 & 23,0 \\
\hline $59-68$ & 18 & 3,6 & Akademisyen & 5 & 1,0 \\
\hline 69 ve üzeri & 3 & 0,6 & Öğrenci & 17 & 3,4 \\
\hline Toplam & 500 & 100 & Ev hanımı & 19 & 3,8 \\
\hline Gelir & & & Diğer & 30 & 6,0 \\
\hline 2000 TL altı & 150 & 30,0 & Toplam & 500 & 100 \\
\hline 2001-3000 TL & 115 & 23,0 & & & \\
\hline 3001-4000 TL & 95 & 19,0 & & & \\
\hline 4001-5000 TL & 73 & 14,6 & & & \\
\hline 5001-6000 TL & 33 & 6,6 & & & \\
\hline $6001-7000 \mathrm{TL}$ & 10 & 2,0 & & & \\
\hline 7000 TL ve üzeri & 24 & 4,8 & & & \\
\hline Toplam & 500 & 100 & & & \\
\hline
\end{tabular}

Ankete katılan cevaplayıcılar çoğunlukla 39-48 yaş aralığında, üniversite eğitimi almış, özel sektör çalışanı, $2000 \mathrm{Tl}$ altı gelire sahip, evli kadınlardan oluşmaktadır.

Çalışmadan elde edilen diğer sonuçla göre cevaplayıcılar sosyal ağlara erişmek için en çok cep telefonu $(\% 53,4)$ tercih etmekte ve sosyal ağ sitelerinden en çok Facebook $(\% 44,2)$ ve İnstagram'ı $(44,0)$ kullanmaktadır. Cevaplayıcıların günlük sosyal ağlarda harcadıkları ortalama süre ise 0-3 saat arasıdır. 


\subsubsection{Araştırma Modelinin Testi}

Araştırma modelinin testine geçmeden önce her bir ölçeğin araştırma örneği için geçerliliğini test etmek amacı ile doğrulayıcı faktör analizi yapılmış ve ölçekler uyum değerleri açısından incelenmiştir. Doğrulayıcı faktör analizi sonucunda bazı ölçeklerin uyum değerlerinin kabul edilebilir sınırlar içinde olmadığı görülmüş ve modifikasyona gidilmiştir. Önerilen modifikasyonlarla birlikte istatistiki bakımından uygun olmayan değişkenler elenmiştir. Modifikasyon sonrası elde edilen değerler Tablo 2'de gösterilmiştir.

Tablo 2: Araştırma Modelinde Yer Alan Değişkenlerin Uyum Iyiliği Değerleri

\begin{tabular}{|c|c|c|c|c|c|c|c|c|c|c|}
\hline & $\mathrm{X}^{2}$ & Df & $x^{2} / d f$ & RMSEA & RMR & AGFI & NFI & CFI & GFI & $\mathbf{P}$ \\
\hline Etik Özellikler & 505,56 & 234 & 2,16 & 0,05 & 0,08 & 0,90 & 0,84 & 0,91 & 0,92 & 0,01 \\
\hline Subjektif Norm & 332,67 & 72 & 4,62 & 0,09 & 0,07 & 0,87 & 0,95 & 0,96 & 0,97 & 0,01 \\
\hline $\begin{array}{l}\text { Sosyal ağ sitelerinin } \\
\text { satın alma davranı- } \\
\text { şına etkisi } \\
\text { Sosyal ağ kullanma }\end{array}$ & 15,23 & 5 & 3,05 & 0,07 & 0,02 & 0,96 & 0,99 & 0,99 & 0,09 & 0,01 \\
\hline $\begin{array}{l}\text { ve algılama } \\
\text { Giyim ve tekstil sek- }\end{array}$ & 123,35 & 40 & 3,08 & 0,07 & 0,07 & 0,93 & 0,89 & 0,92 & 0,96 & 0,01 \\
\hline $\begin{array}{l}\text { törünün çevresel et- } \\
\text { kileri ile ilgili bilgi } \\
\text { sahibi olma }\end{array}$ & 122,96 & 61 & 2,01 & 0,05 & 0,03 & 0,94 & 0,85 & 0,92 & 0,96 & 0,01 \\
\hline Materyalizm & 133,56 & 48 & 2,78 & 0,06 & 0,06 & 0,93 & 0,87 & 0,91 & 0,96 & 0,01 \\
\hline Giysiye ilgilenim & 39,73 & 12 & 3,31 & 0,07 & 0,04 & 0,95 & 0,98 & 0,98 & 0,98 & 0,01 \\
\hline Suçluluk duygusu & 13,81 & 5 & 2,76 & 0,06 & 0,03 & 0,97 & 0,98 & 0,99 & 0,99 & 0,01 \\
\hline $\begin{array}{l}\text { Sosyal kabul görme } \\
\text { ön yargısı }\end{array}$ & 89,29 & 46 & 1,91 & 0,04 & 0,07 & 0,95 & 0,83 & 0,90 & 0,97 & 0,01 \\
\hline $\begin{array}{l}\text { Sürdürülebilir giy- } \\
\text { siye yönelik tutum }\end{array}$ & 62,46 & 14 & 4,46 & 0,08 & 0,04 & 0,92 & 0,97 & 0,98 & 0,07 & 0,01 \\
\hline $\begin{array}{l}\text { Sürdürülebilir giysi } \\
\text { satın alma niyeti }\end{array}$ & 1,854 & 1 & 1,85 & 0,04 & 0,05 & 0,98 & 1,00 & 1,00 & 0,99 & 0,01 \\
\hline
\end{tabular}

Tabloda görüldüğü gibi $\left(X^{2}\right) / d f$ oranları referans değerinin altında, RMSEA değerleri ise kabul edilebilir düzeydedir. Ayrıca NFI, CFI, GFI ve AGFI değerlerinin de kabul edilebilir uyum düzeyinde olduğu görülmektedir.

Doğrulayıcı faktör analizi yapıldıktan sonra araştırma modeli test edilmiştir. Araştırma modelinin testi için yapısal eşitlik analizi kullanılmıştır. Model testi iki aşamada gerçekleşmiştir.

1. Birinci aşamada girdi değişkenler olan etik özellik boyutları, subjektif norm boyutları, giyim ve tekstil sektörünün çevresel etkileri ile ilgili bilgi sahibi olma, sosyal kabul görme ön yargısı, sosyal ağ sitelerinin satın alma davranışına etkisi, sosyal ağ kullanma ve algılama; ara değişken olarak sürdürülebilir giysiye yönelik tutum ve çıktı değişken olarak da sürdürülebilir giysi satın alma niyeti arasındaki ilişkiler test edilmiştir.

2. Daha sonra ise tüketiciler, materyalist eğilimi yüksek olan, materyalist eğilimi düşük olan; giysiyle ilgilenimi yüksek olan, giysiyle ilgilenimi düşük olan; suçluluk duygusu yüksek olan, suçluluk duygusu düşük olan şeklinde gruplandırılarak moderatör ilişkiler test edilmiştir.

Birinci aşamada girdi, ara ve çıktı değişkenler arasındaki ilişkinin incelendiği, analiz sonucunda elde edilen yapısal model içerisindeki istatistiki değerler ve model uyum indeksleri Tablo 3'de gösterilmiştir. 
Tablo 3: Modele Ait Yapısal Model Standardize Yol Katsayıları

\begin{tabular}{|c|c|c|c|c|c|}
\hline & Estimate & S.E & C.R. & $\begin{array}{l}\text { Standardize Edil- } \\
\text { miş Katsayılar }\end{array}$ & $\mathbf{P}$ \\
\hline Altruizm-Tutum & 072 & 021 & 3,017 & 140 & ,003 \\
\hline Etik Kaygı - Tutum &,- 026 & 021 & $-1,206$ &,- 060 & ,228 \\
\hline Etik Yükümlülük - Tutum & 048 & 024 & 1,970 & 100 & ,048 \\
\hline Normatif İnanç - Tutum & 108 & 028 & 3,796 & 180 & 001 \\
\hline Normlara Uyma Motivasyonu -Tutum &,- 008 & 021 &,- 378 & $-0,20$ & ,706 \\
\hline Sosyal Ağ Kullanma ve Algılama- Tutum & 001 & 025 & 051 & 010 & 960 \\
\hline Sosyal Ağların Satın Alma Davranışına Etkisi- Tutum & ,059 & 022 & 2,718 & 160 & 007 \\
\hline $\begin{array}{l}\text { Sosyal Ağların Satın Alma Davranışına Etkisi- Satın } \\
\text { Alma Niyeti }\end{array}$ & 178 & ,048 & 3,702 & 140 & ,001 \\
\hline $\begin{array}{l}\text { Giyim ve Tekstil Sektörünün Çevresel Etkilerine İliş- } \\
\text { kin Bilgi Sahibi Olma - Tutum }\end{array}$ &,- 028 & 044 &,- 636 &,-030 & ,525 \\
\hline $\begin{array}{l}\text { Giyim ve Tekstil Sektörünün Çevresel Etkileri İle İlgili } \\
\text { Bilgi Sahibi Olma - Satın Alma Niyeti }\end{array}$ &, 517 & 120 & 4,312 & 160 & ,001 \\
\hline Tutum - Satın Alma Niyeti & 1,726 & 124 & 13,882 & ,490 & ,001 \\
\hline Sosyal Kabul Görme Ön Yargısı - Tutum &,- 018 & 028 &,- 653 &,-030 & ,514 \\
\hline
\end{tabular}

RMSEA: 0,061, RMR: 0,012, Chi/Square/df: 2,810, p-value = 0,010, GFI: 0,995, CFI: 0,990, AGFI: 0,931, NFI: 0,986

Elde edilen bu sonuçlar Şekil 2' de gösterilmiştir.

Şekil 2: Tüm Tüketiciler Için Yapısal Eşitlik Diyagramı
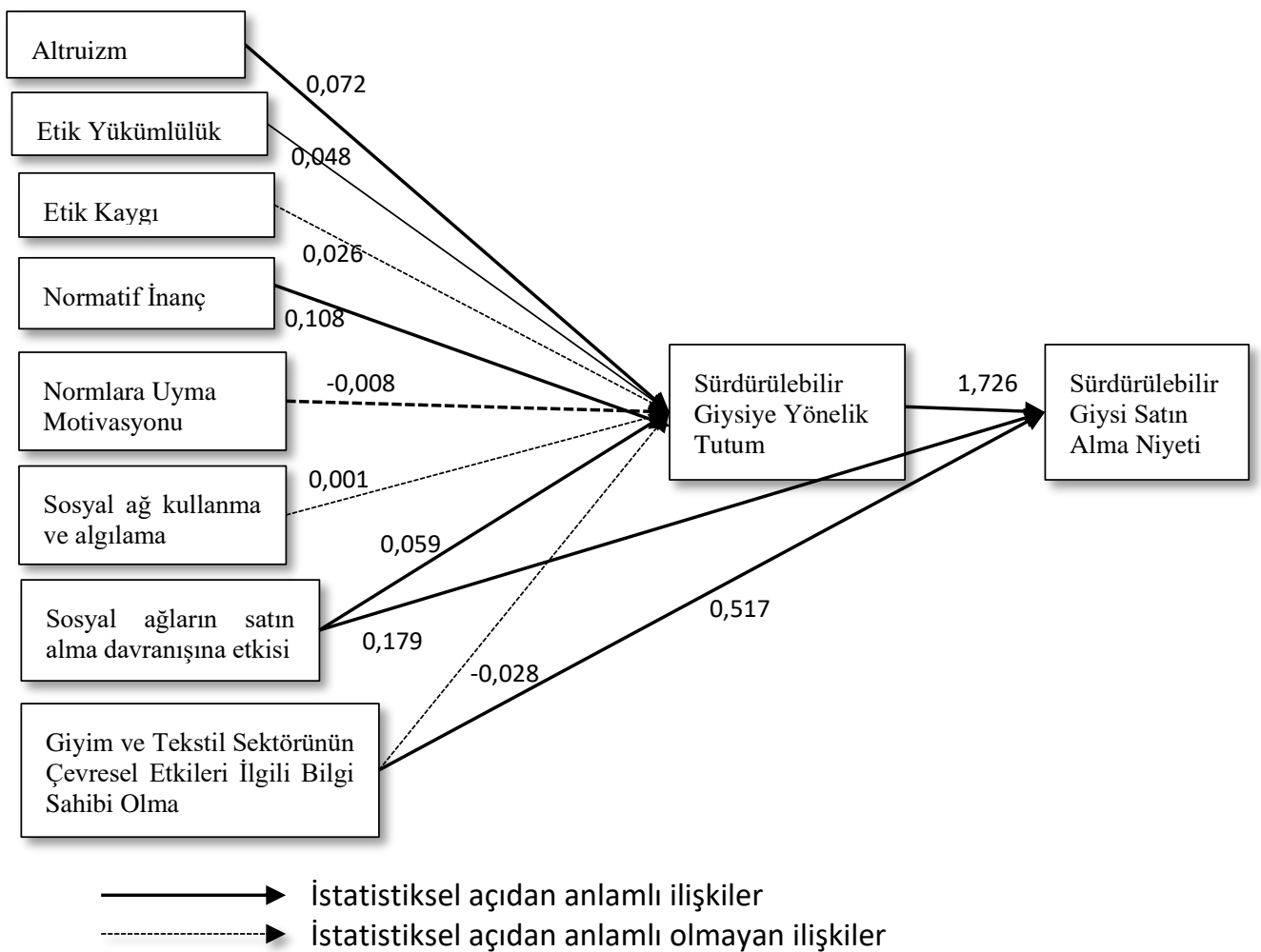

Bu durumda;

$\mathrm{H}_{1 a}$ : Altruizm sürdürülebilir giysiye yönelik tutumu olumlu yönde etkilemektedir, hipotezi desteklenmiştir. 
$\mathrm{H}_{1 b}$ : Etik kaygı sürdürülebilir giysiye yönelik tutumu olumlu yönde etkilemektedir, hipotezi desteklenmemiştir.

$\mathrm{H}_{1 c}$ : Etik yükümlülük sürdürülebilir giysiye yönelik tutumu olumlu yönde etkilemektedir, hipotezi desteklenmiştir.

$\mathrm{H}_{2 \mathrm{a}}$ : Normatif inançlar sürdürülebilir giysiye yönelik tutumu olumlu yönde etkilemektedir, hipotezi desteklenmiştir.

$\mathrm{H}_{2 b}$ : Normlara uyma motivasyonu sürdürülebilir giysiye yönelik tutumu olumlu yönde etkilemektedir, hipotezi desteklenmemiştir.

$\mathrm{H}_{3}$ : Sosyal ağları kullanma ve algılama sürdürülebilir giysiye yönelik tutumu olumlu yönde etkilemektedir, hipotezi desteklenmemiştir.

$\mathrm{H}_{4 a}$ : Sosyal ağların genel satın alma davranışına etkisi sürdürülebilir giysi satın alma niyetini olumlu yönde etkilemektedir, hipotezi desteklenmiştir.

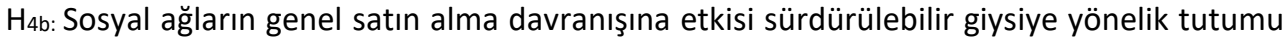
olumlu yönde etkilemektedir, hipotezi desteklenmiştir.

$\mathrm{H}_{5 a}$ : Giyim ve tekstil sektörünün çevresel etkileri ile ilgili bilgi sahibi olma, sürdürülebilir giysi satın alma niyetini olumlu yönde etkilemektedir, hipotezi desteklenmiştir.

$\mathrm{H}_{5 b}$ : Giyim ve tekstil sektörünün çevresel etkileri ile ilgili bilgi sahibi olma, sürdürülebilir giysiye yönelik tutumu olumlu yönde etkilemektedir, hipotezi desteklenmemiştir.

$\mathrm{H}_{6}$ : Sürdürülebilir giysiye yönelik tutum sürdürülebilir giysi satın alma niyetini olumlu yönde etkilemektedir, hipotezi desteklenmiştir.

Araştırma modelinde yer alan değişkenler arasındaki ilişkiler test edildikten sonra materyalizm, giysiye ilgilenim ve suçluluk duygusunun moderatör etkileri test edilmiştir. Moderatör etkiler test edilirken öncelikle katılımcılar materyalist eğilimi düşük olan, materyalist eğilimi yüksek olan; giysiye ilgilenimi düşük olan, giysiye ilgilenimi yüksek olan; suçluluk duygusu düşük olan, suçluluk duygusu yüksek olan şeklinde gruplandırılmıştır. Buna göre;

Materyalist eğilimi yüksek olan ve materyalist eğilimi düşük olan; giysiye ilgilenimi yüksek olan, giysiye ilgilenimi düşük olan; suçluluk duygusu yüksek olan, suçluluk duygusu düşük olan gruplar için \%95 güven aralığında Z testi yapılmış ve güven aralığı 0,123 olarak hesaplanmıştır. $Z$ testi sonucuna göre belirlenen gruplarla ilgili bilgiler Tablo 4'te gösterildiği gibidir.

Tablo 4. Grup Bilgileri

\begin{tabular}{lll}
\hline Materyalizm eğilimi yüksek olan kişiler & Ortalama>3,093 & 162 Kişi \\
Materyalizm eğilimi düşük olan kişiler & Ortalama<2,85 & 236 Kişi \\
Giysiye ilgilenimi yüksek olan kişiler & Ortalama>3,373 & 234 Kişi \\
Giysiye ilgilenimi düşük olan kişiler & Ortalama<3,127 & 198 Kişi \\
Suçluluk duygusu yüksek olan kişiler & Ortalama>2,66 & 223 Kişi \\
Suçluluk duygusu düşük olan kişiler & Ortalama<2,41 & 226 Kişi \\
\hline
\end{tabular}

Sonraki aşamada AMOS 20 ve Exel programları kullanılarak belirlenmiş olan alt gruplar için Ki-kare farklılıkları hesaplanmış ve moderatör etkiler ortaya çıkarılmıştır.

\subsubsection{Materyalizmin Moderatör Etkisinin Test Edilmesi}

Materyalizmin sürdürülebilir giysiye yönelik tutum ve sürdürülebilir giysi satın alma niyeti arasında düzenleyici (moderatör) etkiye sahip olup olmadığını belirlemek için Ki-Kare farklılığı testi yapılmış ve sonuçlar Tablo 5'te gösterilmiştir. 
Tablo 5: Materyalizme ilişkin Ki-Kare Farklılıkları Testi Sonucu

\begin{tabular}{|c|c|c|c|c|c|c|c|}
\hline & & & \multicolumn{2}{|c|}{ Düşük Materyalizm } & \multicolumn{2}{|c|}{ Yüksek Materyalizm } & \multirow[b]{2}{*}{ z-score } \\
\hline & & & Estimate & $\mathbf{P}$ & Estimate & $\mathbf{P}$ & \\
\hline Tutum & $<--$ & Alturizm & 0,066 & 0,034 & 0,086 & 0,063 & 0,370 \\
\hline Tutum & $<---$ & Etiksel Yükümlük & 0,029 & 0,355 & 0,098 & 0,042 & 1,197 \\
\hline Tutum & $<---$ & Normatif İnanç & 0,105 & 0,007 & 0,068 & 0,187 & $-0,578$ \\
\hline Tutum & $<--$ & Normlara Uyma Motivasyonu & 0,003 & 0,923 & $-0,002$ & 0,960 & $-0,098$ \\
\hline Tutum & $<--$ & Sosyal Kabul Görme Ön Yargısı & $-0,016$ & 0,682 & $-0,024$ & 0,651 & $-0,112$ \\
\hline Tutum & $<--$ & Bilgi & 0,004 & 0,950 & $-0,039$ & 0,601 & $-0,425$ \\
\hline Tutum & $<--$ & $\begin{array}{l}\text { Sosyal Ağ Kullanma ve Algı- } \\
\text { lama }\end{array}$ & $-0,011$ & 0,759 & 0,050 & 0,224 & 1,106 \\
\hline Tutum & $<--$ & $\begin{array}{l}\text { Sosyal Ağların Satın Alma Dav- } \\
\text { ranışına Etkisi }\end{array}$ & 0,067 & 0,017 & 0,020 & 0,640 & $-0,921$ \\
\hline Tutum & $<---$ & Etiksel Kaygı & $-0,023$ & 0,430 & $-0,016$ & 0,696 & 0,135 \\
\hline $\begin{array}{l}\text { Satın Alma Ni- } \\
\text { yeti }\end{array}$ & $<--$ & Tutum & 2,114 & 0,001 & 1,173 & 0,001 & $-3,494 * * *$ \\
\hline $\begin{array}{l}\text { Satın Alma Ni- } \\
\text { yeti }\end{array}$ & $<--$ & $\begin{array}{l}\text { Sosyal Ağların Satın Alma Dav- } \\
\text { ranışına Etkisi }\end{array}$ & 0,153 & 0,025 & 0,123 & 0,153 & $-0,267$ \\
\hline $\begin{array}{l}\text { Satın Alma Ni- } \\
\text { yeti }\end{array}$ & $<--$ & Bilgi & 0,655 & 0,001 & 0,464 & 0,020 & $-0,687$ \\
\hline
\end{tabular}

Notes: ${ }^{* * *}$ p-value $<0.01 ; * *$ p-value $<0.05 ;{ }^{*}$ p-value $<0.10$

Ki-Kare farklılığı testi sonucuna göre materyalizm tutum ve satın alma niyeti arasında moderatör etkiye sahiptir. Tabloya göre düşük materyalist eğilim bireylerin sürdürülebilir giysi satın alma niyetini olumlu yönde etkilerken, yüksek materyalist eğilim ise tüketicilerin sürdürülebilir giysi satın alma niyetini olumsuz yönde etkilemektedir. Bu durumda;

$\mathrm{H}_{7}$ : “Materyalizm sürdürülebilir giysiye yönelik tutum ile sürdürülebilir giysi satın alma niyeti arasındaki ilişkide moderatör etkiye sahiptir", hipotezi desteklenmiştir.

\subsubsection{Giysiye İlgilenimin Moderatör Etkisinin Test Edilmesi}

Giysiye ilgilenimin sürdürülebilir giysiye yönelik tutum ve sürdürülebilir giysi satın alma niyeti arasında düzenleyici (moderatör) etkiye sahip olup olmadığını belirlemek için Ki-Kare farklılığı testi yapılmış ve sonuçlar Tablo 6'da gösterilmiştir.

Tablo 6: Giysiye Illgilenime Ilişkin Ki- Kare Farklılıkları Testi Sonucu

\begin{tabular}{|c|c|c|c|c|c|c|c|}
\hline & & & \multicolumn{2}{|c|}{$\begin{array}{l}\text { Düşük Giysiye } \\
\text { İlgilenim }\end{array}$} & \multicolumn{2}{|c|}{$\begin{array}{l}\text { Yüksek Giysiye } \\
\text { İlgilenim }\end{array}$} & \multirow[b]{2}{*}{ z-score } \\
\hline & & & Estimate & $\mathbf{P}$ & Estimate & $\mathbf{P}$ & \\
\hline Tutum & $<---$ & Altruizm & 0,105 & 0,001 & 0,027 & 0,459 & $-1,593$ \\
\hline Tutum & $<---$ & Etik Yükümlülük & $-0,032$ & 0,354 & 0,104 & 0,004 & $2,727 * * *$ \\
\hline Tutum & $<---$ & Etik Kaygı & $-0,018$ & 0,537 & $-0,042$ & 0,212 & $-0,537$ \\
\hline Tutum & $<---$ & Normatif İnanç & 0,103 & 0,011 & 0,105 & 0,010 & 0,031 \\
\hline Tutum & $<---$ & Normlara Uyma Motivasyonu & $-0,001$ & 0,978 & 0,009 & 0,792 & 0,216 \\
\hline Tutum & $<---$ & Sosyal Kabul Görme Ön Yargısı & 0,068 & 0,086 & $-0,077$ & 0,075 & ,473 \\
\hline Tutum & $<---$ & Bilgi & $-0,011$ & 0,866 & $-0,085$ & 0,206 & $-0,809$ \\
\hline Tutum & $<---$ & Sosyal Ağ Kullanma ve Algılama & $-0,034$ & 0,339 & 0,015 & 0,688 & 0,956 \\
\hline Tutum & $<---$ & $\begin{array}{l}\text { Sosyal Ağların Satın Alma Davra- } \\
\text { nışına Etkisi }\end{array}$ & 0,092 & 0,001 & 0,039 & 0,243 & $-1,213$ \\
\hline $\begin{array}{l}\text { Satın Alma } \\
\text { Niyeti }\end{array}$ & $<---$ & Tutum & 2,135 & 0,001 & 1,398 & 0,001 & $-2,647 * * *$ \\
\hline $\begin{array}{l}\text { Satın Alma } \\
\text { Niyeti }\end{array}$ & $<---$ & $\begin{array}{l}\text { Sosyal Ağların Satın Alma Davra- } \\
\text { nışına Etkisi }\end{array}$ & 0,203 & 0,008 & 0,148 & 0,029 & $-0,540$ \\
\hline $\begin{array}{l}\text { Satın Alma } \\
\text { Niyeti }\end{array}$ & $<---$ & Bilgi & 0,618 & 0,001 & 0,340 & 0,054 & $-1,084$ \\
\hline
\end{tabular}

Notes: $* *$ p-value $<0.01 ; * *$ p-value $<0.05 ; *$ p-value $<0.10$ 
Ki-Kare farklılığı testi sonucuna göre giysiye ilgilenim; tutum ve satın alma niyeti, etik yükümlülük ve tutum arasında moderatör etkiye sahiptir. Tabloya göre giysiye ilgilenimin düşük olması sürdürülebilir giysi satın alma niyetini olumlu yönde etkilerken; giysiye ilgilenimin yüksek olması sürdürülebilir giysi satın alma niyetini azaltıcı yönde etkilemektedir. Bu durumda

$\mathrm{H}_{8}$ : "Giysiye ilgilenim sürdürülebilir giysiye yönelik tutum ve sürdürülebilir giysi satın alma niyeti arasındaki ilişkide moderatör etkiye sahiptir", hipotezi desteklenmiştir.

\subsubsection{Suçluluk Duygusunun Moderatör Etkisinin Test Edilmesi}

Suçluluk duygusunun sürdürülebilir giysiye yönelik tutum ve sürdürülebilir giysi satın alma niyeti arasında düzenleyici (moderatör) etkiye sahip olup olmadığını belirlemek için Ki-Kare farklıı̆̆ı testi yapılmış ve sonuçlar Tablo 7'de gösterilmiştir.

Tablo 7: Suçluluk Duygusuna ilişskin Ki- Kare Farlııkları Testi Sonucu

\begin{tabular}{|c|c|c|c|c|c|c|c|}
\hline & & & \multicolumn{2}{|c|}{ Düşük Suçluluk } & \multicolumn{3}{|c|}{ Yüksek Suçluluk } \\
\hline & & & Estimate & $\mathbf{P}$ & Estimate & $\mathbf{P}$ & z-score \\
\hline Tutum & $<--$ & Altruizm & 0,048 & 0,167 & 0,065 & 0,063 & 0,348 \\
\hline Tutum & $<--$ & Etik yükümlülük & 0,077 & 0,030 & 0,013 & 0,733 & $-1,255$ \\
\hline Tutum & $<--$ & Etik kaygı & $-0,038$ & 0,210 & $-0,054$ & 0,102 & $-0,358$ \\
\hline Tutum & $<--$ & Normatif inanç & 0,144 & 0,001 & 0,055 & 0,182 & $-1,495$ \\
\hline Tutum & $<--$ & Normlara Uyma Motivasyonu & 0,008 & 0,806 & $-0,083$ & 0,010 & $2,026 * *$ \\
\hline Tutum & $<---$ & Sosyal Kabul Görme Ön Yargısı & $-0,050$ & 0,201 & $-0,004$ & 0,929 & 0,804 \\
\hline Tutum & $<---$ & Bilgi & $-0,081$ & 0,219 & 0,032 & 0,620 & 1,226 \\
\hline Tutum & $<--$ & Sosyal Ağ Kullanma ve Algılama & 0,015 & 0,672 & 0,008 & 0,815 & $-0,136$ \\
\hline Tutum & $<--$ & $\begin{array}{l}\text { Sosyal Ağların Satın Alma Davra- } \\
\text { nışına Etkisi }\end{array}$ & 0,028 & 0,358 & 0,120 & 0,001 & $2,012 * *$ \\
\hline $\begin{array}{l}\text { Satın alma } \\
\text { niyeti }\end{array}$ & $<---$ & Tutum & 1,404 & 0,001 & 1,840 & 0,001 & $-1,694 *$ \\
\hline $\begin{array}{l}\text { Satın alma } \\
\text { niyeti }\end{array}$ & $<---$ & $\begin{array}{l}\text { Sosyal Ağların Satın Alma Davra- } \\
\text { nışına Etkisi }\end{array}$ & 0,152 & 0,049 & 0,282 & 0,001 & 1,270 \\
\hline $\begin{array}{l}\text { Satın alma } \\
\text { niyeti }\end{array}$ & $<--$ & Bilgi & 0,744 & 0,001 & 0,241 & 0,150 & $2,008 * *$ \\
\hline
\end{tabular}

Notes: ${ }^{* * *}$ p-value $<0.01 ; * *$-value $<0.05 ;{ }^{*}$ p-value $<0.10$

Ki- Kare farklılığı testi sonucuna göre suçluluk duygusu; tutum ve bilgi ile satın alma niyeti arasında, sosyal ağların satın alma davranışına etkisi ve aynı zamanda normlara uyma motivasyonu ile tutum arasında moderatör etkiye sahiptir. Tabloya göre suçluluk duygusunun yüksek hissedilmesi bireylerin sürdürülebilir giysi satın alma niyetlerini olumlu yönde etkilerken, suçluluk duygusunun az hissedilmesi sürdürülebilir giysiye yönelik tutum ile satın alma niyeti arasındaki ilişkiyi zayıflatmaktadır. Bu durumda;

$\mathrm{H}_{9}$ : "Suçluluk duygusu sürdürülebilir giysiye yönelik tutum ve sürdürülebilir giysi satın alma niyeti arasındaki ilişkide moderatör etkiye sahiptir", hipotezi desteklenmiştir.

\section{Sonuç ve Öneriler}

Tüketicilerin sürdürülebilir giysiye yönelik tutum ve satın alma niyetlerinin kapsamlı olarak araştırıldığı bu çalışmadan elde edilen sonuçlar şöyledir:

Ankete katılanlar çoğunlukla 39-48 yaş aralığında, üniversite eğitimi almış, özel sektör çalışanı, 2000 TL ve üzeri gelire sahip, evli kadınlardan oluşmaktadır. Katılımcıların çoğunluğu sosyal ağlara erişmek için en çok cep telefonu kullanılmakta ve sosyal ağlarda günlük 0-3 saat harcamaktadırlar. Ayrıca elde edilen sonuca göre katılımcılar sosyal ağ sitelerinden en çok Facebook ve İnstagramı kullanmaktadır.

Araştırma modelinin test edilmesi sonucu elde edilen bulgular ise şu şekildedir: 
Birinci aşamada araştırma modelindeki girdi değişkenler olan etik özellik boyutları (alturizm, etik kaygı, etik yükümlülük), subjektif norm boyutları (normlara uyma motivasyonu, normatif inanç), giyim ve tekstil sektörünün çevresel etkileri ile ilgili bilgi sahibi olma, sosyal kabul görme ön yargısı, sosyal ağ sitelerinin satın alma davranışına etkisi, sosyal ağ kullanma ve algılama, ara değişken olarak sürdürülebilir giysiye yönelik tutum ve çıktı değişken olarak da sürdürülebilir giysi satın alma niyeti arasındaki ilişkiler test edilmiştir. Elde edilen sonuca göre; altruizm, etik yükümlülük, sosyal ağların etkisi ve normatif inançlar sürdürülebilir giysiye yönelik tutumu pozitif yönde etkilemekte; giyim ve tekstil sektörünün çevresel etkileri ile ilgili bilgi sahibi olma ve sosyal ağların etkisi sürdürülebilir giysi satın alma niyetini pozitif yönde etkilemektedir. Ayrıca sürdürülebilir giysiye yönelik tutum ise sürdürülebilir giysi satın alma niyetini pozitif yönde etkilemektedir. Bu doğrultuda, $\mathbf{H}_{1 a}, \mathbf{H}_{1 c}, \mathbf{H}_{2 a}, \mathbf{H}_{4 a}, \mathbf{H}_{4 b}, \mathbf{H}_{5 a}, \mathbf{H}_{6}$ hipotezleri desteklenmiştir. $\mathbf{H}_{1 b}, \mathbf{H}_{2 b}, \mathbf{H}_{3}$, $\mathbf{H}_{5 \mathbf{b}}$, hipotezleri desteklenmemiştir.

Elde edilen bulguları değerlendirmek gerekirse; sürdürülebilir giysiye yönelik tutum üzerinde özellikle etik özelliklerin etkili olması, bireylere giysi bağlamında sürdürülebilir tüketim davranışlar kazandırma açısından önemli bir sonuçtur. Niinimaki (2015)' e göre değerler ve etik, sürdürülebilir giysi ya da sürdürülebilir modanın temel dayanağını oluşturmaktadır. Buna göre sürdürülebilir giysiye yönelik tutumu pozitif yönde etkileyen altruistik (özgecil) değerler toplumsal açıdan değerlendirildiğinde, bencil olmamayı, işbirliği ve yardımlaşmayı önemsemeyi aynı zamanda topluma karşı sorumluluk taşıyıp o yönde davranışlar sergilemeyi gerektirmektedir. Elde edilen sonuca göre, bireylerin sahip olduğu bu değerler onları çevresel açıdan daha hassas davranmaya yöneltip, sürdürülebilir giysi tüketimine yönelik tutumlarını da olumlu yönde etkilemektedir. Araştırmada ayrıca altruistik değerlerin yanı sıra etik yükümlülüğün de bireylerin sürdürülebilir giysiye yönelik tutumlarını pozitif yönde etkilediği tespit edilmiştir. Bu durumda bireylerin kendi tutum ve davranışlarının neden olduğu çevresel sorunları göz ardı etmeyip çevresel ve etik açıdan yükümlülük taşımaları onların sürdürülebilir giysiye yönelik olumlu tutum geliştirmelerine neden olmaktadır. Etik özelliklere ilişkin ortaya çıkan bu sonuçlar literatürle de desteklenmektedir (Bae, 2012; Reimers ve Magnuson, 2017; Mostafa 2006).

Araştırmada elde edilen diğer bir sonuca göre, normatif inançlar sürdürülebilir giysiye yönelik tutumu pozitif yönde etkilemektedir. Buna göre bireylerin sürdürülebilir giysiye yönelik olumlu tutum geliştirmelerini, çevrelerinde ya da sosyal ağ sitelerinde kendileri için önemli kişi veya referans gruplarının nasıl değerlendireceği yönündeki inançları belirleyebilmektedir. Ajzen (1985)'e göre çevreci davranışlar söz konusu olduğunda, bireyin çevreci davranışla ilgili olumlu tutuma sahip olması ve önem verdiği kişilerin bu davranışı desteklemesi, bireyin çevreci davranma konusunda üzerinde bir baskı hissetmesine ve o yönde davranışsal niyet sergilemesine yol açmaktadır. Dolayısıyla araştırma sonucu ortaya çıkan bu durum literatürle de desteklenmektedir (Onel ve Mukherjee, 2015; Albayrak vd. 2012; Shin ve Hancer, 2016).

Elde edilen bir diğer bulgu ise, sosyal ağların satın alma davranışına etkisinin bireylerin sürdürülebilir giysiye yönelik tutumunu ve satın alma niyetini olumlu etkilemesidir. Bu sonuca göre; bireyler için sosyal ağların özellikle de Instagram'ın önemi büyüktür. Sosyal ağların bireyler için önemli olması ve satın alma davranışlarını etkileyip yönlendirmesi, aynı zamanda bireylerin sürdürülebilir giysiye yönelik tutumunu ve satın alma niyetini olumlu yönde etkilemektedir. Araştırmada ayrıca giyim ve tekstil sektörünün çevresel etkilerine ilişkin bilgi sahibi olma bireylerin sürdürülebilir giysi satın alma niyetini olumlu yönde etkilediği ortaya çıkmıştır. Bu 
durum literatürle desteklenmektedir. Reiter (2015) ve Hiller Connel ve Kozar (2011)'e göre giyim ve tekstil sektöründeki çevresel konularla ilgili bilgi sahibi olunması bireylerin tutumlarını ve davranışlarını etkileyebilmektedir.

Araştırma modelinin testinin ikinci aşamasında moderatör ilişkiler test edilmiştir. Materyalizmin, giysiyle ilgilenimin ve suçluluk duygusunun sürdürülebilir giysiye yönelik tutum ve sürdürülebilir giysi satın alma niyeti arasındaki moderatör etkilerini tespit etmek için Ki-Kare farkIılığı testi yapılmıştır. Moderatör ilişkiler açısından elde edilen sonuçlar ise şu şekildedir:

Materyalizmin moderatör etkisine ilişkin ortaya çıkan sonuca göre; düşük materyalist eğilim bireylerin sürdürülebilir giysi satın alma niyetini olumlu yönde etkilerken, yüksek materyalist eğilim ise bireylerin sürdürülebilir giysi satın alma niyetini azaltıcı yönde etkilemektedir. Bu durumda materyalizmin sürdürülebilir giysiye yönelik tutum ile sürdürülebilir giysi satın alma niyeti arasında moderatör etkiye sahip olduğu söylenebilir. Dolayısıyla materyalizm bireylerin tutum ve davranışlarına etki ederek davranışları yönlendirmesi bakımından önem taşımaktadır. Materyalizm ile çevresel davranışlar arasındaki ilişkinin araştırıldığı birçok çalışma da bu çalışmaya benzer olarak materyalist eğilim ile çevreci davranışlar arasında negatif yönlü ilişki bulunduğu tespit edilmiştir (Banerjee ve McKeage, 1994; Polonsky vd. 2014; Hurst vd. 2013).

Giysiye ilgilenimin moderator etkisine bakıldığında ise; giysiye ilgilenimin düşük oluşu bireylerin sürdürülebilir giysi satın alma niyetlerini olumlu yönde etkilerken, giysiye ilgilenimin yüksek oluşu sürdürülebilir giysi satın alma niyetini olumsuz etkilemektedir. Ortaya çıkan sonuç giysiye ilgilenimin sürdürülebilir giysiye yönelik tutum ile sürdürülebilir ile sürdürülebilir giysi satın alma niyeti arasında moderatör etkiye sahip olduğunu göstermektedir. Suçluluk duygusuna ilişkin elde edilen sonuçlar değerlendirildiğinde; suçluluk duygusunun sürdürülebilir giysiye yönelik tutum ve sürdürülebilir giysi satın alma niyeti arasında moderatör etkiye sahip olduğu ortaya çıkmıştır. Bu durum, bireylerin suçluluk duygusunu yoğun hissetmeleri sürdürülebilir giysi satın alma niyetini olumlu yönde etkilerken, suçluluk duygusunu daha az hissetmeleri sürdürülebilir giysi satın alma niyetlerini olumsuz yönde etkiler şeklinde yorumlanabilir. Suçluluk duygusu ve giysiye ilgilenim için elde edilen bu bulgular konuyla ilgili literatürdeki çalışmalardan elde edilen sonuçlarla benzerlik göstermektedir (Tarkiainen ve Sundqvist, 2009; Arli vd., 2009; Steenhaut ve Kenhove, 2006; Lindenmeir vd.,2017). Materyalizm, giysiyle ilgilenim ve suçluluk duygusunun moderatör etkilerine ilişkin ortaya çıkan bu sonuca göre; $\mathbf{H}_{7}, \mathbf{H}_{\mathbf{8}}$ VE $\mathbf{H}_{9}$ hipotezleri desteklenmiştir.

Çalışmadan elde edilen sonuçlar doğrultusunda şu önerilerde bulunulabilir:

Sonuçlar bireylerin çoğunlukla etik değerlere önem verdiğini ve tutumlarını da o yönde şekillendirdiğini göstermektedir. Bu noktada sürdürülebilir tüketim açısından etik olgusunun önemli bir belirleyici olduğunu söylemek mümkündür. Sürdürülebilir tüketim etik çerçevesinde ele alındığında, etik değerlerin çocukluktan başlayarak örgün ve yaygın eğitimle bireylere benimsetilmesi gerekmektedir. Değerlerin küçük yaşta oluştuğu düşünüldüğünde bireylere kazandırılan bu etik değerler tüm yaşamları boyunca onlara çevresel ve sosyal sorumluluk bilinci ile hareket etmede rehberlik edecektir. Dolayısıyla aile başta olmak üzere okul ve yakın çevre etik değerlerin bireylere benimsetilmesinde temel ve önemli unsurlardandır. Bu bağlamda eğitim sürecinin başlangıcı olan ilköğretimden itibaren sürdürülebilirlik, etik, sosyal sorumluluk veya çevresel konularla ilgili dersler müfredata eklenerek toplumsal bilincin küçük yaşlardan itibaren oluşması sağlanabilir. 
Sürdürülebilir tüketimin teşviki, bireylerin sürdürülebilir ürünlere olumlu tutum geliştirmesi ve satın alma isteklerinin arttırılmasında etkin biçimde kullanılması gereken diğer bir araç iletişim kanallarıdır. Özellikle son yıllarda sosyal medya ve paralelinde sosyal ağların bireylerin yaşamlarında önemli yer tutması, bireylere sürdürülebilir tüketim davranışı kazandırma açısından oldukça önemlidir. Sosyal ağ platformlarında birçok markanın aktif olarak yer alması ve kullanıcılarla bu yolla bağlantı kurması bireylerin satın alma kararlarını büyük oranda etkilemektedir. Çalışmayla ilgili olarak değerlendirmek gerekirse; çevreye duyarlı sürdürülebilir giysi üreten firma ya da markalar sosyal ağ ortamlarını hedef kitlelerine ulaşmada ve onların tutum ve davranışlarını etkilemede bir araç olarak kullanabilirler. İşletmeler bu mecralarda hedef kitleleriyle direkt etkileşime geçerek onların tutum ve davranışlarını etkileyebilirken aynı zamanda sosyal ağ sitelerini, ürünleri ile ilgili normatif inançları iletebilecekleri bir platform olarak da kullanabilir. Bu bağlamda işletmeler özellikle e-WOM sayesinde doğrudan ya da hedef kitleleri için önemli kişi ya da referans grupları vasıtasıyla iletişim kurup, hedef kitlenin inançlarına etki ederek onların sürdürülebilir giysi tüketimine yönelik tutum ve davranışlarına yön verebilir. Ayrıca çalışmaya göre tüketiciler sosyal ağ ortamlarından en fazla Instagram ve Facebook'u kullanmaktadır. Çevreye duyarlı sürdürülebilir giysi üreten firmalar özellikle bu mecraları hedef kitlelerine ulaşmak ve daha fazla potansiyel tüketiciyi etkilemek için fırsat olarak değerlendirebilirler.

Hali hazırda moda endüstrisi son derece hızlı üretim döngülerine, hızlı değişen moda eğilimlerine ve ürünlerin planlı demodeliğine dayanmaktadır (Niimaeki, 2013) (Planlı demodelik; endüstri açısından müşterilerin kısa sürede yeni ürün almalarını teşvik ederek talep artışına neden olur ve üretici yararına potansiyel avantaj sağlar (Türkmen; 2012)). Dolayısıyla giysi ve moda alanlarında sürdürülebilirlik bağlamında bir dönüşüm yaratabilmek için radikal değişimlere ihtiyaç duyulduğu açıktır. Bu anlamda gerek tüketici ve üreticiler gerekse tüm paydaşlar sürdürülebilir kalkınmaya katkıda bulunmak için bir kazan-kazan durumu yaratmalıdırlar. Tüketiciler açısından bakıldığında, giyim ve tekstil endüstrisinde sürdürülebilir tüketime doğru bir dönüşüm yaratmak için bilgilendirme sürecine ihtiyaç duyulmaktadır. Çalışmadan elde edilen sonuç göstermiştir ki bireyler giyim ve tekstil endüstrisinin çevresel etkileri ile ilgili çok fazla bilgiye sahip değiller. Dolayısıyla gerek kamu kuruluşlarının ilgili birimleri gerekse de sivil toplum örgütleri, sosyal ağ ortamları başta olmak üzere her türlü platformda tüketicileri bu konuyla ilgili bilgilendirmeli, eğitim programları düzenlenmeli ve giyim tercihlerinde tüketicilerin hem kendi sağlıkları hem de çevresel ve sosyal refaha katkıda bulunmaları için sürdürülebilir ürünleri tercih etmeleri sağlanmalıdır.

Tasarımcılar ve üretici firmalar açısından değerlendirmek gerekirse; giysi üretim aşamasında kimyasal madde kullanımını minimuma indirgeyerek, daha kaliteli ve uzun ömürlü ürünler üreterek tüketicilerin üründen memnuniyetini sağlayabilirler. Aslında üründen memnuniyeti giysi tüketimi dolayısıyla da üretimini yavaşlatmak için bir fırsat olarak değerlendirmek mümkündür. Çünkü üründen memnuniyetle birlikte planlı demodeliğe karşı tüketicilerin ürünleri daha uzun süreli kullanmaları sağlanabilir. Ayrıca işletmeler tüketicilerde sürdürülebilir giysi veya moda ürünlerine yönelik talep oluşturmak için, ürünlerine tüketiciler için önemli değerler ekleyebilir. Özellikle sürdürülebilir ürünlerin tasarım aşamalarında etik ve çevresel değerlerin estetikle birleştirilmesi sürdürülebilir giysiye olan tüketici taleplerini artırabilir. Ayrıca tüketicilerin sürdürülebilir giysi kullanarak sosyal çevrelerinde bir fark yaratabilecekleri konusunda ikna edecek iletişim stratejileri de tüketicilerin bu ürünlere yönelik taleplerini olumlu yönde etkileyecektir.

Sürdürülebilir giysiye talep oluşturulmasının yanı sıra diğer önemli faktör ise tüketicilerin bu yönde davranışlarını kısıtlayan unsurların ortaya çıkarılmasıdır. Bu çalışmaya göre materyalist 
kişilik özelliği ve bireylerin giysiye ilgileniminin yüksek oluşu sürdürülebilir davranışları kısıtlayan unsurlardandır. Dolayısıyla işletmeler özelliklede pazarlama departmanları materyalizmi körükleyen iletişim stratejilerinden vazgeçmeli; iletişim mesajlarını etik kaygılar ile hazırlamalıdır. Ayrıca materyalizme karşı daha az tüketimle daha çok mutluluk ve tatmin yaratılacağı sade yaşam tarzları özendirilmelidir. Bunun için ise, toplum tarafından kabul görmüş, saygı duyulan ve sevilen kişiler aracı olabilir. Bu kişilerin sürdürülebilir giysiyle ilgili vermiş oldukları mesajları veya yaşam tarzları ile örnek olmaları bireylerin düşünce ve tutumlarını değiştirmeye yardımcı olabilir.

Tüketicilerin sürdürülebilir yöntemlerle üretilmeyen giysileri satın aldıklarında bu satın alımlarının sonuçlarını gösterecek aynı zamanda vicdanen rahatsızlık hissetmeleri ve suçluluk duymalarını sağlamak için kamu spotları hazırlanabilir. Böylece kamu spotları mesajlarıyla tüketicilerde oluşturulan suçluluk duygusu, onları giysi tercihlerinde sürdürülebilir tercihler yapmalarına neden olabilir.

Bugün artık bilinmektedir ki hızlı moda bireylerin daha çok giysi tüketimine ve giysiyle ilgili algılarının değişmesine neden olmaktadır. Giyim günümüzde fonksiyonel işlevlerinin yanı sıra bireylerin duygusal ve hedonik ihtiyaçlarını karşılama, kendinin ifade etme, aynı zamanda sembolik ve sosyal etkileşimi sağlamada bir araç olarak algılanmaktadır (Cho vd.2015). Tüm bu algılar bireylerin giysiye ilgilenimin artmasına ve daha çok giysi tüketimine neden olmaktadır. Bu bağlamda hem tasarımcılara hem de ülke yöneticilerine görevler düşmektedir. Tasarımcılar giysi tasarımlarını artık çevresel anlayışla yapmalı, hızlı moda yerine sürdürülebilirlik perspektifinde yavaş moda prensibini benimseyerek sürdürülebilir giysileri tüketicileri cezbedecek şekilde tasarlamalıdırlar. Böylece tüketicilerin sürdürülebilir giysilere yönelik ilgilenimlerinin artması sağlanabilir. Ülke yöneticileri ise tasarımlarını çevresel duyarlııkla yapan ve sürdürülebilirliğe katkı sağlayan tasarımcılara teşvikler vermeli ve onları ödüllendirmelidir. Giysileri çevreye duyarlı ve sürdürülebilir şeklinde tasarlayarak ve üreterek aslında marka imajlarının, marka değerlerinin ve karlılıklarının artacağı sıklıkla vurgulanmalı ve buna ikna edilmelidirler. 


\section{Eskişehir Osmangazi Üniversitesi ïiBF Dergisi}

Kaynaklar

Ajzen, Icek (1991), "The Theory of Planned Behavior", Organizational Behavior and Human Decison Processes, 50(2), 179-211.

Albayrak, Tahir; Aksoy, Şafak; Caber, Meltem (2012), "The Effect of Environmental Concern and Scepticism on Green Purchase Behaviour". Marketing Intelligence \& Planning, 31(1), 27-39.

Alsop, Dee. T; Bassett, Bryce. R; Hoskins, James. A. (2007). "Word of Mouth Research: Principles and Applications". Journal of Advertising Research, 47 (4), 398-411.

Arli, Denni; Leo, Cheryl; Tjiptono, Fandy (2016)."Investigating The Impact of Guilt and Shame Proneness on Consumer Ethics: A Cross National Study", International Journal of Consumer Studies, 40, 2-13.

Bae, Su Yun (2012). Understanding Ethical Consumers: Assessıng The Moderatıng Effects of Price Sensitivity, Materialism, Impulse Buying Tendency. For the Degree of Master of Science. Colarado: Colarado State University.

Bakar, Abou; Lee, Richard; Hashim, Noor Hazarina (2013). "Parsing Religiosity, Guilt and Materialism on Consumer Ethics".Journal of Islamic Marketing, 4(3), 232-244.

Banerjee, Bobby; McKeage. Kim (1994), “How Green Is My Value: Exploring The Relationship Between Environmentalism And Materialism", Advances in Consumer Research, 21, 147-152.

Barnett, Clive; Cloke, Paul (2010). Globalizing Responsibility: The Political Rationalities Of Ethical Consumption. Chichester: John Wiley \& Sons, Ltd.

Barutçu. Süleyman; Toma, Melda (2013). "Sürdürülebilir Sosyal Medya Pazarlaması Ve Sosyal Medya Pazarlaması Etkinliğinin Ölçümü”, Internet Uygulamaları ve Yönetimi Dergisi, 4(1), 5-24.

Belk, Russel W. (1985). “Materialism: Trait Aspects of Living in the Material World”, Journal of Consumer Research, 12(3), 265-279.

Bickart, Barbara; Schindler, Robert. M. (2001). "Internet Forums as Influential Sources of Consumer Information” . Journal of Interactive Marketing, 15(3), 31-40.

Brennan, L.inda; Binney, Wayne (2010). "Fear, Guilt, and Shame Appeals in Social Marketing". Journal of Business Research, 63(2), 140-146.

Cengiz, Hakan (2017). "Effect of The Need for Popularity on Purchase Decision Involvement and Impulse Buying Behavior Concerning Fashion Clothing". Journal of Global Fashion Marketing 8(2), 113-124

Cervellon, Marie-Cecile; Hjert, Helena; Ricard, Sandina (2010), "GREEN IN FASHION? An exploratory study of national differences in consumers concern for eco-fashion, https://www.compromisorse.com/upload/estudios/000/114/GreenFashion.pdf. Erişim Tarihi: 10 Ocak 2018

Cho, Erin; Gupta, Shipra; Kim, Young-Kyung. (2015). "Style Consumption: Its Drivers and Role in Sustainable Apparel Consumption", International Journal of Consumer Studies, 39, 661-669

Cohen, Taya R.; Panter, A.T., Turan, Nazlı (2013). "Predicting Counterproductive Work Behavior from Guilt Proneness", Journal of Business Ethics, 114, 45-53.

Cowe, Roger; Williams, Simon (2000). Who are the ethical consumers?. Manchester: UK: Cooperative Bank.

Culiberg, Barbara; Bajde, Domen(2013). “Consumer Recycling: An Ethical Decision-Making Process”, Journal of Consumer Behaviour, J. Consumer Behavior. 12: 449-459.

Darban, Ayda; Li, Wei.(2012), The Impact Of Online Social Networks On Consumers' Purchasing Decision, (Master's Thesis). Within Business Administration Jönköping University.

De Groot, Judith I. M; Steg, Linda (2008). "Value Orientations to Explain Beliefs Related to Environmental Significant Behavior: How to Measure Egoistic, Altruistic, and Biospheric Value Orientations". Environment and Behavior, 40(3), 330-354

Dickson, Marsha A. (2000). "Personal Values, Beliefs, Knowledge, and Attitudes Relating to Intentions to Purchase Apparel From Socially Responsible Businesses". Clothing and Textiles Research Journal, 18(1), 19-30.

Diddi, Sonali (2014), Understanding Ethical Consumption Decisions: The Role Of Values, Attitudes And Expectations in The Apparel Purchasing Context, (Doctor Of Phılosophy), lowa: lowa State University

Dietz, Thomas; Fitzgerald, Amy; Shwom, Rachael (2005), "Environmental values", Annual Review of Environment and Resources, 30(1), 335-372.

Dunlap, Riley; Liere, Kent; Merting, Angela (2000). “"Measuring Endorsement Of The New Ecological Paradigm: A Revised NEP Scale". Journal of Social Issues, 56(3), 425-482. 
Eckhardt, Giana; Belk, Russell; Devinney, Timoty, (2010). "Why Don't Consumers Consume Ethically", Journal of Consumer Behaviour 9(6):426 - 436

Elsner, Mark. K; Heil, Oliver. P; Sinha, Atanu. R. (2010). How Social Networks Influence The Popularity Of User- Generated Content. Special Report 10-206. Marketing Science Institute.

Eren, Esra (2014), "Sosyal Medya Kullanım Amaçları Ölçeğinin Geliştirilmesi ve Bazı Kişisel Değişkenlere Göre İncelenmesi", Hacettepe Üniversitesi Eğitim Fakültesi Dergisi, 29(4), 230-243.

Fairhurst, Ann; Good, Linda; Gentry, James (1989). "Fashion İnvolvement: An Instrument Validation Procedure". Clothing and Textiles Research Journal, 7(3), 10- 14

Freedman, Jonathan; Wallington, Sue; Bless, Evelyn (1967). "Compliance Without Pressure: The Effects of Guilt”, Journal of Personality and Social Psychology, 7, 117-124

Gates, Donld; Steane, Peter (2009)." Altruism: An Alternative Value İn Policy Formation And Decision Making". International Journal of Social Economics, 36(10), 962- 978.

Global Fashion Agenda, Boston Consulting Group (2017), Pulse Of Fashion Industry Report. http: //globalfashionagenda.com/wp-content/uploads/2017/05/Pulse- of-the-Fashion Industry_2017.pdf. Erişim Tarihi: 10 Ocak 2018.

Godes, David; Mayzlin, Dina. (2004). “Using Online Conversations To Study Word-Of-Mouth Communication” ,Marketing Science, 23(4), 545-560

Gürce, Merve. Yanar: Benli, Müzeyyen. (2017), “Online Tüketici Yorumlarının Satın Alma Niyetine Etkisi: Genç Tüketicilere Yönelik Bir Araştırma”, Journal of Current Researches on Business and Economics, 7(1), 1-18

Heinonen, Kristina. (2011), “Consumer Activity in Social Media: Managerial Approaches To Consumers' Social Media Behavior", Journal of Consumer Behaviour, 10, 356-364

Hennig-Thurau, Thorsten; Kevin P. Gwinner, Gianfranco Walsh ve Dwayne D. Gremler; (2004), "Electronic Word-OfMouth Via Consumer Opinion Platforms: What Motivates Consumers To Articulate Themselves On The Internet?", Journal Of Interactive Marketing, 18(1), 38-52.

Hibbert, Sally; Smith, Andrew; Davies, Andrea; Ireland, Fiona (2007). “Guilt appeals: Persuasion Knowledge and Charitable Giving". Psychology \& Marketing, 24(8), 723-742.

Hiller Connel, Kim (2011), “Exploring Consumers' Perceptions Of Eco-Conscious Apparel Acquisition Behaviors”, Social Responsibility Journal, 7(1), 61-73.

Hitlin, Steven (2003), "Values As the Core of Personal Identity: .Drawing Links Between Two Theories of Self", Social Psychology Quarterly, 66(2), 118-137.

Homer, Pamela.;Kahle, Lynn (1988). "A Structural Equation Test of the Value-Attitude Behavior Hierarchy". Journal of Personality and Social Psychology, 54, 638-646.

Hurst, Megan; Dittmar, Helga; Bond, Rod; Kasser, Tim (2013), "The Relationship Between Materialistic Values And Environmental Attitudes And Behaviors: A Meta-Analysis", Journal of Environmental Psychology, 36, 257-269.

Hustvedt, Gwendolyn; Dickson, Marsha. (2009). “Consumer Likelihood of Purchasing Organic Cotton Apparel: Influence of Attitudes And Self-identity". Journal of Fashion Marketing and Management, 13(1), 49-65.

İşlek, Mahmut Sami (2012). Sosyal Medyanın Tüketici Davranışlarına Etkileri: Türkiye'deki Sosyal Medya Kullanıcıları Üzerine Bir Araştırma, (Yayımlanmamış Yüksek Lisans Tezi). Karaman: Karamanoğlu Mehmetbey Üniversitesi Sosyal Bilimler Enstitüsü.

Jagel, Thomas; Keeling, Kathy; Repper, Alexander (2012), "Individual Values And Motivational Complexities in Ethical Clothing Consumption: A Means-End Approach", Journal of Marketing Management, 28(3-4), 373-396.

Jones, Chiristie; Kim, Soyoung (2010). "Influences of Retail Brand Trust, Off-Line Patronage, Clothing İnvolvement and Website Quality on On-Line Apparel Shopping İntention", International Journal of Consumer Studies 34, 627-637.

Joung, Huyun- Mee(2013). "Materialism and Clothing Post-Purchase Behaviors”. Journal of Consumer Marketing, 30(6), 530-537.

Kaiser, Florian G., Shimoda, Todd A. (1999). "Responsibility as a Predictor of Ecological Behavior". Journal of Environmental Psychology, 19, 243-253

Kang, Jiyun; Liu, Chuanlan., Kim, Sang (2013). “Environmentally Sustainable Textile and Apparel Consumption: The Role of Consumer Knowledge, Perceived Consumer Effectiveness And Perceived Personal Relevance", International Journal of Consumer Studies, 37, 442-452 


\section{Eskişehir Osmangazi Üniversitesi ïBß Dergisi}

Kılıç, Sümeyya (2013). Giyim Sektöründeki Üretim Artıklarının Sürdürülebilir Moda Yaklaşımı Ile Değerlendirilmesi ve Örnek Bir Uygulama. (Yayımlanmamış Yüksek Lisans Tezi), Ankara: Gazi Üniversitesi Eğitim Bilmleri Enstitüsü.

Kilbourne, William; Pickett, Gregory (2008). “How Materialism Affects Environmental Beliefs, Concern, And Environmentally Responsible Behavior", Journal of Busines Research, 61(9), 885-893.

Lindenmeier, Jörg; Lwin, Michael; Andersch, Henrike (2017). “Anticipated Consumer Guilt: An Investigation Into its Antecedents and Consequences for Fair-Trade Consumption". Journal of Macromarketing, 37(4), 444-459

Markkula, Annu; Moisander, Johanna (2012). “Discursive Confusion Over Sustainable Consumption: A Discursive Perspective on The Perplexity of Marketplace Knowledge". Journal of Consumer Policy, 35(1), 105-125.

McNeill, Lisa; Moore, Rebecca (2015). "Sustainable Fashion Consumption And The Fast Fashion Conundrum: Fashionable Consumers and Attitudes To Sustainability in Clothing Choice". International Journal of Consumer Studies, 39(3), 212-222.

Mittal, Banwari; Lee, Myung (1989). "A Casual Model of Consumer Involvement". Journal of Economic Psychology, 10(3), 363-389

Mostafa, M. Mostafa (2006). “Antecedents Of Egyptian Consumers' Green Purchase Intentions”. Journal of International Consumer Marketing, 19(2), 97-126.

Muncy, James A; Eastman, Jacqueline K. (1998), "Materialism And Consumer Ethics: An Exploratory Study”, Journal of Business Ethics, 17 (2), 137-145.

Niinimaki, Kirsi (2010). "Eco-clothing, Consumer Identity and Ideology". Sustainable Development, 18, 150-162.

O'Cass, Aron (2000). “An Assessment Of Consumers Product, Purchase Decision, Advertising And Consumption İnvolvement İ Fashion Clothing", Journal of Economic Psychology, 21, 545-76.

O'Cass, Aron (2001). "Consumer Self-monitoring, Materialism and Involvement in Fashion Clothing”, Australasian Marketing Journal, 9 (1), 46-60

O'Cass, Aron (2004). "Fashion Clothing Consumption: Antecedents And Consequences Of Fashion Clothing İnvolvement". European Journal of Marketing, 38(7), 869-882.

Oh, Jong-Chul; Sung-Joon (2014). "Theory-Based Approach To Factors Affecting Ethical Consumption”, International Journal of Consumer Studies, 38, 278-288

Onel, Naz; Mukherjee, Avinandan (2015). “Understanding Environmentally Sensitive Consumer Behaviour: An İntegrative Research Perspective”. World Journal of Entrepreneurship, Management and Sustainable Development, 11 (1), 2-16

Onwezen, Marleen C; Antonides, Gerrit; Bartles, Jos (2013). “The Norm Activation Model: An Exploration Of The Functions Of Anticipated Pride And Guilt in Pro-Environmental Behaviour", Journal of Economic Psycholgy, 39, 141-153

Oral, Okşan;Dirgar, Esra;Erdoğan, Çetin., (2012). "Tekstil ve Hazır Giyim Üretiminde Ekoloji” [Bildiri], 1. Uluslararası Moda ve Tekstil Tasarımı Sempozyumu

Özaslan, Yasin; Meydan Uygur, Selma. (2014). “Negatif Ağızdan Ağıza İletişim ve Elektronik Ağızdan Ağıza Illetişim: Yiyecek-iç̧ecek İşletmelerine Yönelik Bir Araştırma”. Atatürk Üniversitesi İktisadi ve Idari Bilimler Dergisi, 28 (3), 6988.

Park, Eun Joo; Kim, Eun Young Forney, Judith Cardona. (2006). "A Structural Model Of Fashion-Oriented Impulse Buying Behavior". Journal of Fashion Marketing and Management, 10(4), 433-445.

Peloza, John; White, Katherine Shang, Jingzhi (2013). “Good And Guilt-Free: The Role of Sel Accountability İn İnfluencing Preferences For Products With Ethical Attributes". Journal of Marketing, 77(1), 104-119.

Polonsky, Michael; Kilbourne, William; Vocino, Andrea (2014). "Relationship Between The Dominant Social Paradigm, Materialism And Environmental Behaviours in Four Asian Economiesé, European Journal of Marketing, 48(3/4) , 522-551.

Reimers, Vaughan; Magnuson, Bryce (2017), “Happiness, Altruism And The Prius Effect How Do They Influence Consumer Attitudes Towards Environmentally Responsible Clothing?", Journal of Fashion Marketing and Management, 21(1), 115-132.

Reiter, Lauren(2015), Investıgatıng The Role of Socıal Networkıng Sites In Increasıng Purchase Intention For Environmentally Sustaınable Apparel, An Exploratory Study,(Doctor Of Phılosophy,) Kansas: Kansas State Unıversıty Manhattan.

Richins, M.L. and Dawson, S. (1992), “A Consumer Values Orientation for Materialism and its Measurement: Scale Development and Validation", Journal of Consumer Research, 19(3) 303-316. 
Richins, Marsha (2004), "The Material Values Scale: Measurement Properties and Development of A Short Form". Journal ofConsumer Research, 31(1), 209-219.

Rushton, Philippe; Chrisjohn, Roland; Fekken, Cynthia (1981), "The altruistic personality and the self-report altruism scale". Personality and Individual Differences, 2, 293-302.

Ryan, Tanya (2014), The Role of Beliefs in Purchase Decisions: A Look at Green Purchase Behavior and Altruism, A Dissertation Submitted to the Faculty of the University of Minnesota.

Seo, Jung; Hathcote, Jan; , Sweaney, Anne (2001), "Casual wear Shopping Behavior Of College Men In Georgia, USA", Journal of Fashion Marketing and Management, 5(3), 208-22.

Shaw, Deirdre; Shui, Edward; Hogg, Gillian; Wilson, Elaine(2004), "Fashion Victim?: The Impact of Sweatshop Concerns on Clothing Choice" [Bildiri]. Proceedings of the 33rd European Marketing Academy Conference, Murcia, Spain.

Shin, Yeon; Hancer, Murat (2016). "The Role Of Attitude, Subjective Norm, Perceived Behavioral Control And Moral Norm in The Intention to Purchase Local Food Products". Journal Of Food Service Business Research, (19)4,338351

Sneddon, Joanna Nicola; Souttar, Geoffrey; Lee, Ann Julie (2013). “Exploring Wool Apparel Consumers' Ethical Concerns And Preferences". Journal of Fashion Marketing and Management, 18(2), 169-186.

Sparks, Paul; Shepherd, Richard; Frewer, Liynn(1995). “Assessing And Structuring Attitudes Toward the Use of Gene Technology in Food Production: The Role of Perceived Ethical Obligation". Basic and Applied Social Psychology, 16(3), 267-285.

Sparks, Paul; Shepherd, Richard (2002), "The Role of Moral Judgments Within Expectancy Value- Based Attitude-Behavior Models". Ethics and Behavior, 12, 299-321.

Steenhaut, Sarah; Kenhove, Patrich Van (2006). 'The Mediating Role of Anticipated Guilt in Consumers' Ethical Decision-Making', Journal of Business Ethics 69(3), 269- 288.

Tangney, Juni Price (1996), "Conceptual and Methodological Issues in the Assessment of Shame and Guilt". Behaviour Research and Therapy, 34 (9), 741-54.

Tangney, June Price; Miller, Rowland; Flicker, L.aura; Barlow, Deboraah, Hill (1996), "Are Shame, Guilt, An Embarrassment Distinct Emotions?" Journal of Personality and Social Psychology, 70, 12-56.

Tarkiainen, Anssi; Sundqvist, Sanna (2009), “Product İnvolvement in Organic Food Consumption: Does Ideology Meet Practice?", Psychology \& Marketing, 10(11), 808-822.

Theotokis, Aristeidis; Manganari, Emmanouela (2015), "The Impact of Choice Architecture on Sustainable Consumer Behavior: The Role of Guilt", Journal Businnes Ethics, 131, 423-437.

Türkmen, Nesrin (2012), “Sürdürülebilir Bir Tekstil Endüstrisi İçin "Yavaşlık” ve Alternatif Üretim Modelleri” [Bildiri], 1. Uluslararası Moda ve Tekstil Tasarımı Sempozyumu.

Vermeir, Irıs; Verbeke, Wim (2006), "Sustaınable Food Consumptıon: Explorıng The Consumer Attitude - Behavıoral Intentıon Gap", Journal of Agricultural and Environmental Ethics, 19, 169-194.

Whitley, Cameron; Takahashi, Bruno; Zwicklec, Adam; Besleyd, John (2018), "Sustainability Behaviors Among College Students: An Application of the VBN Theory. Environmental Education Research, 24 (2), 245-262.

Yücel, Sibel; Tiber, Bahar (2018), “Hazır Giyim Endüstrisinde Sürdürülebilir Moda”, Tekstil Ve Mühendis, 25(112), 368380

Zaichkowsky, Lynne (1985), “Measuring The İnvolvement Construct”. Journal Of Consumer Research, 12(3), 341-352 


\title{
Eskişehir Osmangazi Üniversitesi iißB Dergisi
}

\section{Extended Summary}

\author{
Evaluation of Ethics Element in Purchasing Sustainable Clothing: A Research On Social Network Users
}

Textile and clothing sector is an industry branch which plays an important role in the economic development of the countries, and it is one of the first sectors of the industrialization process. However, in recent years with the advance in technology the developments textile sector plays an important role in the increase of environmental problems, just like in many other sectors. Especially the fashion industries to impose of excessive consumption causes these problems to grow even more. Fast fashion causes environmental and social effects. These effects, such as low wages in the production and consumption process, working condition of the workers and child labor etc., the excessive use of resources and wastes, the harmful effects of the toxic chemicals on human health. Therefore, necessitate sustainability in all production and consumption processes of the industry.

The way of encouragement the production of high quality sustainable clothes that are environmentally harmless, produced from completely renewable sources, can be recycled at the same time is possible only by creating demand for these products in consumers. In order to create demand for consumers, basic factors affecting consumers' perceptions, attitudes and behaviors must be revealed. In this context, the aim of this study is to investigate the attitudes and buying intentions of individuals towards sustainable clothing within the framework of ethic traits. . In addition, whether social networking is a potential field that can positively influence buying intentions and attitudes of the consumers toward sustainable clothing, the regulatory effect of materialism, clothing involvement and guilt feelings have been tried to be investigated. The main group of the study consists of consumers be older than 18 years old and living in Istanbul. The framework of the main group is composed of consumers who actively use social networking sites be older than 18 years old and in Istanbul.

In this research, data were collected using the survey method. A professional research firm was hired to assist in obtaining the data. The survey was conducted in thirteen central districts of Istanbul that are Besiktas, Sisli, Avcilar, Beyoglu, Fatih, Kucukcekmece, Bakirkoy, Kadikoy, Uskudar, Atasehir, Maltepe, Pendik, and Kartal. Face-to-face survey method. Two main criteria that are being older than 18 years old and being active social media users were taken into account while applying a face-to-face survey method. The data was collected between October 15 - November 20, 2017, with 500 participants.

The collected data were statistically analyzed using SPPS20.0 and AMOS 20.0 software. Descriptive statistics, Confirmatory Factor Analysis (CFA), and Structural Equation Modeling (SEM) analysis were used.

Input variables in the research model: Ethical Traits, Subjective Norms, Social Network Use and Perception, Social Networking Sites Influence on Purchase Behavior, Knowledge About Clothing and Textiles Industry Environmental Sustainability Issues

Intermediate variable in the research model: Attitudes Towards Environmentalliy Sustainable Clothing

Output variable in the research model: Environmentally Sustainable Clothing Purchase Intention

Moderatör variable: Individual Characteristics. Feeling Guilt

The hypotheses formed in line with the purpose are as follows.

$\mathrm{H}_{1}$ : Ethical characteristics will have positively affect the attitude towards sustainable clothing. This research hypothesis is divided into the following sub-hypothesis:

$\mathrm{H}_{1 \mathrm{a}}$ : Altruism will have positively affects the attitude towards sustainable clothing.

$\mathrm{H}_{1 b}$ : Ethical converns will have positively affects the attitude towards sustainable clothing.

$\mathrm{H}_{1 c}$ : Ethical obligation will have positively affects the attitude towards sustainable clothing

$\mathrm{H}_{2}$ : The subjective norm related to sustainable clothing will have positively affects the attitude towards sustainable clothing. This research hypothesis is divided into the following sub-hypotheses.

$\mathrm{H}_{2 \mathrm{a}}$ : Normative beliefs will have positively affect the attitude towards sustainable clothing.

$\mathrm{H}_{2 b}$ : Motivation to comply will have positively affects the attitude towards sustainable clothing.

$\mathrm{H}_{3}$ : Social networks use and perception will have positively affects the attitude towards sustainable clothing.

$\mathrm{H}_{4 a}$ : Social networking sites influence on purchase behavior will have positively affects the intention to purchase sustainable clothing 
Aralık 2020, C. 15, S. 3

$\mathrm{H}_{4 \mathrm{~b}}$ : Social networking sites influence on purchase behavior will have positively affects the attitude towards sustainable clothing.

$\mathrm{H}_{5 a}$ : Knowledge about apparel and textiles industry environmental sustainability issues

will have positively affects the intention to purchase sustainable clothing.

$\mathrm{H}_{5 b}$ : Knowledge about apparel and textiles industry environmental sustainability issues

will have positively affects the attitude towards sustainable clothing.

$\mathrm{H}_{6}$ : Attitude towards sustainable clothing positively affects the intention to purchase sustainable clothing.

$\mathrm{H}_{7}$ : Materialism has a moderator effect on the relationship between attitude towards sustainable clothing and intention to purchase sustainable clothing.

$\mathrm{H}_{8}$ : Clothing involvement has a moderator effect on the relationship between attitude towards sustainable clothing and the intention to purchase sustainable clothing.

$\mathrm{H}_{9}$ : Feeling guilt has a moderator effect on the relationship between attitude towards sustainable clothing and intention to purchase sustainable clothing.

Confirmatory factor analysis was performed before the research model was tested and the scales were examined in terms of compliance values. The research model was tested after confirmatory factor analysis. The model test took place in two stages.

1. In the first stage, were tested the relationships between input variables, intermediate variable and output variable.

2. Consumers were grouped in terms of moderator variables and moderator relationships were tested.

According to the results, altruism, ethics obligation, and influence of social networks on purchasing behavior and normative beliefs are effective on the attitudes toward sustainable clothing. The environmental knowledge of individuals, effects of social networks on purchasing behavior, and the attitude towards sustainable clothing are all effective on the intention of purchasing sustainable clothing. In addition, the higher the tendency towards materialism and clothing involvement, the more unfavorable the intention of individuals to buy sustainable clothing; it has been found that the intensity of the feeling of guilt positively affects the individual's intention to buy sustainable clothing. In this instance $\mathrm{H}_{1 a}, \mathrm{H}_{1 c}, \mathrm{H}_{2 a}, \mathrm{H}_{4 a}, \mathrm{H}_{4 b}, \mathrm{H}_{5 a}, \mathrm{H}_{6}$ hypotheses are supported. $\mathrm{H}_{1 b}, \mathrm{H}_{2 b}, \mathrm{H}_{3}, \mathrm{H}_{5 b}$, hypotheses are not supported. 
Eskişehir Osmangazi Üniversitesi ïBF Dergisi 